\title{
CAMA
}

Centre for Applied Macroeconomic Analysis

\section{Price Discovery in Agricultural Commodity Markets: Do Speculators Contribute?}

\section{CAMA Working Paper 42/2019 June 2019}

Martin T. Bohl

Department of Economics, Westfälische Wilhelms-Universität Münster

\section{Pierre L. Siklos}

Department of Economics, Wilfrid Laurier University

Centre for Applied Macroeconomic Analysis, ANU

\section{Martin Stefan}

Department of Economics, Westfälische Wilhelms-Universität Münster

\section{Claudia Wellenreuther}

Department of Economics, Westfälische Wilhelms-Universität Münster

\begin{abstract}
Previous literature on price discovery in commodity markets is mainly focused on the question of whether the spot or the futures market dominates the price discovery process. Little attention, however, has been paid to the question of how the price discovery process is affected by futures speculation. Using different measures for speculation and hedging and a new price discovery metric, the present study analyzes this relationship for various agricultural commodities. On the whole, the results suggest that speculative activity reduces the level of noise in the futures markets under analysis, while increasing their relative contribution to the price discovery process.
\end{abstract}




\title{
Keywords
}

Commodity Markets, Futures Speculation, Price Discovery

\author{
JEL Classification
}

G13, G14, Q02

Address for correspondence:

(E) cama.admin@anu.edu.au

ISSN 2206-0332

The Centre for Applied Macroeconomic Analysis in the Crawford School of Public Policy has been established to build strong links between professional macroeconomists. It provides a forum for quality macroeconomic research and discussion of policy issues between academia, government and the private sector.

The Crawford School of Public Policy is the Australian National University's public policy school, serving and influencing Australia, Asia and the Pacific through advanced policy research, graduate and executive education, and policy impact. 


\title{
Price Discovery in Agricultural Commodity Markets: Do Speculators Contribute?a
}

\author{
Martin T. Bohl ${ }^{b}$ Pierre L. Siklos ${ }^{c}$ Martin Stefan ${ }^{d}$ \\ Claudia Wellenreuther ${ }^{\mathrm{e}}$
}

June 3, 2019

\begin{abstract}
Previous literature on price discovery in commodity markets is mainly focused on the question of whether the spot or the futures market dominates the price discovery process. Little attention, however, has been paid to the question of how the price discovery process is affected by futures speculation. Using different measures for speculation and hedging and a new price discovery metric, the present study analyzes this relationship for various agricultural commodities. On the whole, the results suggest that speculative activity reduces the level of noise in the futures markets under analysis, while increasing their relative contribution to the price discovery process.
\end{abstract}

Keywords: Commodity Markets, Futures Speculation, Price Discovery

JEL codes: G13, G14, Q02

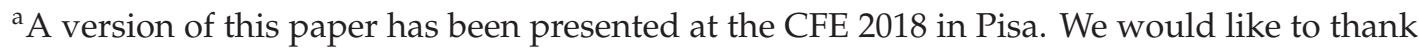
the conference participants, in particular Christopher L. Gilbert, Celso Brunetti and Craig Pirrong, for their helpful and valuable comments. Moreover, we are grateful for the comments of the editor and two anonymous referees.

${ }^{\mathrm{b}}$ Corresponding author: Department of Economics, Westfälische Wilhelms-Universität Münster, Am Stadtgraben 9, 48143 Münster, Germany, Phone: +49 25183 25005, E-mail: martin.bohl@wiwi.uni-muenster.de

${ }^{\mathrm{c}}$ Department of Economics, Wilfrid Laurier University and Centre for Applied Macroeconomic Analysis (CAMA)

${ }^{\mathrm{d}}$ Department of Economics, Westfälische Wilhelms-Universität Münster

${ }^{\mathrm{e}}$ Department of Economics, Westfälische Wilhelms-Universität Münster
} 


\section{Introduction}

In the past decade, the role of speculators in commodity futures markets has been the subject of considerable debate. Public commentators, politicians and market participants have feared that speculation could impair the functioning of futures markets. Two key functions of futures markets are risk transfer and price discovery. Concerning the transfer of risk, the importance of futures speculation is straightforward. Speculators provide liquidity to the market and help hedgers find a matching counterparty to transfer price risk (Keynes 1923, Kaldor 1940). With regard to the price discovery function of futures markets, the role of speculators is, however, less clear.

Previous research has largely focused on determining whether price discovery occurs primarily in the futures market or in the spot market. Across different agricultural commodities, the majority of studies concludes that futures markets dominate the price discovery process (see e.g. Garbade \& Silber 1983, Zapata \& Fortenbery 1996, Yang \& Leatham 1999, Yang et al. 2001). This is in line with the theoretical argument by Grossman (1977) that futures markets are an important place for gathering and exchanging information. However, little attention has been paid to the role of speculation in affecting futures markets' price discovery function. This article sets out to fill this gap in the literature.

Price discovery is defined as the "efficient and timely incorporation of the information implicit in investor trading into market prices" (Lehmann 2002, p. 259). While "efficient" means the relative absence of noise, "timely" refers to how quickly a price series reflects new information about an asset's fundamental value (Putninšs 2013). It seems reasonable to expect that speculation can affect both the level of noise and the processing of new information. Therefore, we follow Yan \& Zivot (2010) and Putninš (2013) who establish a new way of measuring price discovery that specifically allows disentangling these two ele- 
ments of price discovery. Their approach combines two commonly used measures of price discovery, namely the component shares developed by Garbade \& Silber (1983) and Gonzalo \& Granger (1995) as well as the information shares of Hasbrouck (1995) and Lien \& Shrestha (2009). Using a structural vector error correction model, Yan \& Zivot (2010) show that the component shares primarily measure the avoidance of noise, while the information shares capture both the avoidance of noise and the processing of new information. The authors then combine these measures to subtract the noise avoidance component from the information shares to obtain a new metric of informational leadership, which Putninšs (2013) reformulates as information leadership shares.

This article studies the impact of speculation and hedging on information leadership in the price discovery process in four U.S. American agricultural commodity futures markets, namely the markets for corn, soybeans, live and feeder cattle futures. This selection comprises the two largest grains and oilseeds contracts and two livestock contracts. While the former are the most liquid contracts, the latter are among the most illiquid agricultural futures contracts traded in the United States. The case of price discovery is particularly interesting in the markets for soft commodities, as agricultural products generally feature higher storage costs than hard commodities and are supplied by a larger and more heterogeneous group of producers and merchants. This implies a large variety of informational shocks, ranging from local weather phenomena to global shifts in demand patterns, that can affect prices but cannot be set off by inventory adjustments.

Our analysis comprises two steps. First, price data are used to compute time-varying information leadership shares using a rolling window estimation. Second, these price discovery metrics are regressed on different measures of speculative and hedging activity, including the total levels of speculation and hedging as well as the level of excessive speculation as measured by the Work- 
ing's (1960) T index. Here, we rely on trader position data from the Commodity Futures Trading Commission's (CFTC) Commitments of Traders (COT) reports.

Our results indicate that futures speculation significantly enhances the price discovery function of most of the futures markets considered in our analysis. This holds for both the total level of speculation as well as the level of excessive speculation. Conversely, hedging activity is found to reduce the futures market's ability to process new information. This result supports the intuitive idea that hedgers intend to lock in prices for the future, while speculators seek to execute profitable trades by using new information. Hence, speculators are informed traders and important market participants who allow futures markets to fulfill their key functions.

The remainder of this paper is structured as follows. Section 2 outlines the methodology used to measure price discovery and how it is affected by futures speculation, while section 3 describes the data used in this study. The results of this paper are presented in section 4 , which are subsequently tested for their robustness. Lastly, section 5 concludes.

\section{Methodology}

To study the impact of futures speculation on price discovery, a two-step approach is adopted. Based on a simple cost-of-carry model, we first compute time-varying metrics of the relative contributions of the spot and futures markets to the price discovery process. Thereafter, a linear regression analysis is used to investigate how the price discovery function of the futures market is influenced by different measures of speculative and hedging activity. 


\subsection{Cost-of-carry model}

In a simple cost-of-carry model, $S_{t}$ denotes the spot price of a commodity in period $t$ and $F_{t}^{T}$ the price of a futures contract with delivery in period $T$. To carry the commodity from $t$ to $T$, one incurs the cost of carry $(r+c-y) \cdot(T-t)$, where $r$ is the interest rate, $c$ denotes storage and transportation costs and $y$ is the convenience yield. The commodity's spot and futures market are naturally linked by arbitrage. Given that all arbitrage opportunities are exploited, it must hold that

$$
F_{t}^{T}=S_{t} \cdot e^{(r+c-y) \cdot(T-t)}
$$

Taking logs on both sides of the equation yields

$$
f_{t}^{T}=s_{t}+\theta
$$

Here, $f_{t}^{T}$ denotes the logarithm of the futures price and $s_{t}$ that of the spot price. The parameter $\theta$ captures the cost-of-carry-rate. To investigate this relationship empirically, one considers a continuous futures price time series $f_{t}$ and estimates the following equation:

$$
f_{t}=\theta+\xi s_{t}+\varepsilon_{t}
$$

In this equation $\varepsilon_{t}$ resembles white noise, while $\xi$ measures how closely $f_{t}$ is related to $s_{t}$. The unbiasedness hypothesis (Engel 1996, Zivot 2000) implies that the parameter $\xi$ will be equal to one.

Consequently, the following cointegration relationship with a cointegration vector of $(1,-1)$ is obtained:

$$
e c_{t-1}=f_{t-1}-\theta-\xi s_{t-1}
$$


Based on the Granger representation theorem (Engle \& Granger 1987), the relationship between futures and spot prices can be expressed using the following vector error correction (VEC) model, where the operator $\Delta$ denotes first differences:

$$
\begin{aligned}
& \Delta f_{t}=\gamma_{f}+\alpha_{f} e c_{t-1}+\sum_{k=1}^{K} \gamma_{f s, k} \Delta s_{t-k}+\sum_{q=1}^{Q} \gamma_{f f, q} \Delta f_{t-q}+\varepsilon_{f, t}, \\
& \Delta s_{t}=\gamma_{s}+\alpha_{s} e c_{t-1}+\sum_{k=1}^{K} \gamma_{s s, k} \Delta s_{t-k}+\sum_{q=1}^{Q} \gamma_{s f, q} \Delta f_{t-q}+\varepsilon_{s, t} .
\end{aligned}
$$

Parameters $\gamma_{f}$ and $\gamma_{s}$ are the equations' intercepts. The error-correction coefficients $\alpha_{f}$ and $\alpha_{s}$ reflect the speed of adjustment of the two price times series toward the long-run price equilibrium in response to short-run deviations of the system. Conversely, parameters $\gamma_{i j}$ capture the model's short-run dynamics, i.e. how previous changes in market $j=f, s$ affect present changes in market $i=f, s$.

As shown by Stock \& Watson (1988), the VEC model of equation (5) has the following vector moving average (VMA) representation:

$$
\boldsymbol{p}_{t}=\boldsymbol{p}_{0}+\boldsymbol{\Psi}(1) \sum_{i=1}^{t} \varepsilon_{i}+\Psi^{*}(L) \varepsilon_{t}
$$

with

$$
\boldsymbol{p}_{t}=\left(\begin{array}{ll}
f_{t} & s_{t}
\end{array}\right)^{\prime}
$$

where $\boldsymbol{p}_{0}$ is a $(2 \times 1)$ vector of constants and the $(2 \times 2)$ matrix $\boldsymbol{\Psi}(1)$ is the moving average impact matrix. This matrix contains the cumulative VMA coefficients, such that the term $\Psi(1) \sum_{i=1}^{t} \varepsilon_{i}$ summarizes the long-run impact of an innovation at time $t$ on each of the prices. Lastly, $\Psi^{*}(L)$ is a matrix polynomial in the lag operator, $L$, and $\varepsilon_{t}$ is a $(2 \times 1)$ error vector with variance-covariance matrix $\Omega$. Based on the parameters of the VEC and the VMA model, the literature has 
proposed several price discovery measures, which are discussed below.

\subsection{Measuring price discovery}

As explained earlier, price discovery is defined as the efficient and timely incorporation of the information implicit in investor trading into market prices (Lehmann 2002). While "efficient" means the relative absence of noise, "timely" refers to how quickly a price time series reflects new information about an asset's fundamental value (Putninš 2013). To quantify the relative contribution of each market to the price discovery process, different authors have developed various price discovery metrics. However, as argued by Yan \& Zivot (2010) and Putninš (2013), these metrics capture two different aspects of the price discovery process, namely noise avoidance and actual price leadership in the sense of incorporating new information more quickly.

In this sense, a measure for the avoidance of noise is based on the contributions by Garbade \& Silber (1983), Schwarz \& Szakmary (1994) and Gonzalo \& Granger (1995). The latter show how the price vector $\boldsymbol{p}_{t}$ can be decomposed into a permanent (common factor) component and a transitory (stationary) component. The literature has therefore proposed the following two component shares $\left(C S_{f}\right.$ and $\left.C S_{s}\right)$ which can be calculated from the VEC model's long-run adjustment coefficients as

$$
C S_{f}=\frac{\left|\alpha_{s}\right|}{\left|\alpha_{f}\right|+\left|\alpha_{s}\right|} \quad \text { and } \quad C S_{s}=\frac{\left|\alpha_{f}\right|}{\left|\alpha_{f}\right|+\left|\alpha_{s}\right|},
$$

where it holds by construction that $C S_{f}+C S_{s}=1$. It follows from equation (8) that the smaller a market's long-run adjustment coefficient, the greater its component share. Thus, if $\alpha_{f}=0$, the futures market does not react to any deviations from the long-run equilibrium. Consequently, all adjustment to the equilibrium occurs in the spot market. In this case, $C S_{s}=0$ such that the spot 
market is said to make no contribution to the price discovery process, which is then entirely dominated by the futures market.

While these component shares only measure the markets' relative avoidance of noise, an alternative measure developed by Hasbrouck (1995) and Lien \& Shrestha (2009) captures both noise avoidance and the processing of new information. Both argue for making use of the information contained in the variance-covariance matrix of the residuals of equation (5), $\Omega$, in order to account also for the system's short-term dynamics. For this purpose, the authors propose the following information shares

$$
I S_{f}=\frac{\left([\boldsymbol{\Psi} \boldsymbol{F}]_{f}\right)^{2}}{\boldsymbol{\Psi} \Omega \boldsymbol{\Psi}^{\prime}} \text { and } \quad I S_{s}=\frac{\left([\boldsymbol{\Psi} \boldsymbol{F}]_{s}\right)^{2}}{\boldsymbol{\Psi} \Omega \boldsymbol{\Psi}^{\prime}}
$$

where the $(1 \times 2)$ matrix $\boldsymbol{\Psi}$ is either of the two identical rows $\boldsymbol{\Psi}_{1}$ or $\boldsymbol{\Psi}_{2}$ contained in $\Psi(1)$, and $F$ is a transformed version of the error covariance matrix $\Omega{ }^{1}$ To obtain $\boldsymbol{F}$, Hasbrouck (1995) originally advocates the use of a Cholesky factorization. However, depending on the orderings of the prices, this procedure produces two information shares for each market, referred to as upper and lower bounds. Conventionally, averages of these upper and lower bounds are computed. But, in the case of highly divergent bounds, a market's average information share is rather weak in its explanatory power. For this reason, Lien \& Shrestha (2009) propose using an eigen-decomposition of $\Omega$ to obtain a unique matrix $\boldsymbol{F}$ which then circumvents the problem of the Hasbrouck bounds. Simi-

$1 \quad$ Baillie et al. (2002) show that $\Psi$ can directly be obtained from the VEC model in equation (5). In particular, the authors prove that

$$
\boldsymbol{\Psi}(1)=\boldsymbol{\xi}_{\perp} \pi \boldsymbol{\alpha}_{\perp}^{\prime}=\left(\begin{array}{c}
\boldsymbol{\Psi} \\
\boldsymbol{\Psi}
\end{array}\right)=\left(\begin{array}{ll}
\Psi_{1} & \Psi_{2} \\
\Psi_{1} & \Psi_{2}
\end{array}\right)=\pi\left(\begin{array}{ll}
\delta_{f} & \delta_{s} \\
\delta_{f} & \delta_{s}
\end{array}\right),
$$

where $\delta_{f}$ and $\delta_{s}$ denote the orthogonal complements to the vector of error correction adjustment coefficients $\left(\alpha_{\perp}\right)$. The scalar $\pi$ is an arbitrary constant resulting from the computation of the orthogonal complements, which cancels out when calculating the information shares. 
lar to the component shares, these information shares also sum to one and have an analogous interpretation regarding the dominance of either market, i.e. price discovery primarily occurs in the market with the higher information share.

Yan \& Zivot (2010) and Putninšs (2013) note that the component shares, as well as the information shares of Hasbrouck (1995) and the modified version by Lien \& Shrestha (2009), are only able to accurately measure price discovery in the sense of "which market moves first" when both markets exhibit similar levels of noise. This finding is based on a structural cointegration model of Yan \& Zivot (2010). The authors show that the component shares only capture the relative response of the system to transitory shocks, while the information shares measure responses to both transitory shocks and permanent shocks. Consequently, in the case of differing noise levels, the price discovery measures can be higher for two reasons. On the one hand, the price discovery measures are higher if a price time series processes new information more quickly. On the other hand, they are also higher if the price time series contains less noise. Thus, when examining either of the price discovery measures individually, one will not be able to tell which of the two causes dominates.

In order to obtain a price discovery metric that exclusively measures how markets process new information, Yan \& Zivot (2010) propose removing the "noise" component from the existing information shares by dividing the quotient of the information shares by the quotient of the component shares

$$
I L_{f}=\frac{I S_{f}}{I S_{s}} \cdot \frac{C S_{s}}{C S_{f}} \quad \text { and } \quad I L_{s}=\frac{I S_{s}}{I S_{f}} \cdot \frac{C S_{f}}{C S_{s}}
$$

While originally unnamed, Putninš (2013) refers to these two metrics as "information leadership" $(I L)$. To ease interpretation and allow for straightforward comparisons between markets, the author suggests making use of the following 
normalization

$$
I L S_{f}=\frac{I L_{f}}{I L_{f}+I L_{s}} \quad \text { and } \quad I L S_{s}=\frac{I L_{s}}{I L_{f}+I L_{s}}
$$

The resulting information leadership shares $(I L S)$ add up to one, and thus have the same quantitative interpretation as the component and information shares.

In order to obtain a time varying measure of price discovery, this paper estimates equation (5) using a rolling window estimation. In the baseline version we select a window size of 250 trading days which corresponds to one trading year. We also conduct three robustness exercises. First, we decrease the window size to 200 trading days, then increase it to 375 and 500 trading days. While 200 days are roughly the minimum number of observations needed to meaningfully estimate a VEC model, 375 and 500 trading days correspond to one and a half and two whole trading years, respectively. Based on the resulting time-varying estimates for the vector of long-run coefficients $\boldsymbol{\alpha}$ and the variance-covariance matrix of residuals $\Omega$, the three measures of price discovery are computed as explained above. ${ }^{2}$ Comparing how futures speculation affects the different price discovery metrics $C S, I S$ and $I L S$ then allows disentangling the effects that speculation has on either the level of noise or the actual processing of new information in the futures market.

\subsection{The impact of speculation on price discovery}

To measure speculative activity, we rely on trader position data provided in the Commitments of Traders (COT) reports by the Commodity Futures Trading Commission (CFTC). The reports contain data on the end-of-day open interest of three different trader types for a variety of different commodity futures mar-

$2 \quad$ The detailed regression results of the rolling window estimations are available upon request. 
kets: First, there are commercial traders who can be classified as hedgers. The second category consists of non-commercial traders who are generally viewed as speculators. And third, there are traders whose positions fall below the CFTC's minimum reporting standards, such that the nature of these traders' operations is unknown. Some critics argue that this categorization is inaccurate, as some speculators might have an incentive to classify their positions as commercial hedging. While this implies that the commercial category might include some falsely labeled non-commercial positions, it seems satisfactory, based on the existing literature, to treat the non-commercial group as a pure subset of speculators (Sanders et al. 2004, 2010).

The literature suggests various ways of measuring speculative activity using such trader position data. A straightforward measure, which is, e.g., used by Manera et al. (2016), is the total percentage share of open interest held by speculators, $T_{t}$. This measure is defined as

$$
T_{t}=\frac{N C L_{t}+N C S_{t}+\alpha \cdot\left(N R L_{t}+N R S_{t}\right)}{2 \cdot M O I_{t}} \cdot 100 .
$$

Long and short positions of non-commercial speculators are denoted by $N C S_{t}$ and $N C L_{t}$, respectively. Analogously, the positions of non-reporting traders are denoted by $N R L_{t}$ and $N R S_{t}$. Lastly, $M O I_{t}$ resembles market open interest in week $t$, while $\alpha$ captures the fraction of speculative positions among nonreported positions. We follow Rutledge (1977) and Sanders et al. (2010) and allocate non-reported positions to hedging and speculative positions in the same proportions that are observed for reported positions.

Another common measure that specifically aims to capture excessive amounts 
of speculation is Working's (1960) T index, $W_{t}$. This index is defined as

$$
W_{t}=\left\{\begin{array}{ll}
1+\frac{S S_{t}}{H S_{t}+H L_{t}}, & \text { if } H S_{t} \geq H L_{t} \\
1+\frac{S L_{t}}{H S_{t}+H L_{t}}, & \text { if } H S_{t}<H L_{t}
\end{array},\right.
$$

where $S L_{t}, S S_{t}, H L_{t}$ and $H S_{t}$ represent the long and short positions of speculators and hedgers, respectively. These are given by

$$
\begin{aligned}
& S L_{t}=N C L_{t}+\alpha \cdot N R L_{t}, \\
& S S_{t}=N C S_{t}+\alpha \cdot N R S_{t}, \\
& H L_{t}=C L_{t}+(1-\alpha) \cdot N R L_{t}, \\
& H S_{t}=C S_{t}+(1-\alpha) \cdot N R S_{t} .
\end{aligned}
$$

The idea behind this index is that any trade by a hedger will require an opposing trade by a speculator. If hedgers as a whole prefer taking a short position, i.e. $H S_{t} \geq H L_{t}$, then speculators must take a sufficiently large long position for the market to clear. If, however, speculators take a short position, $S S_{t}$, which exceeds the needs of hedgers, this can be regarded as a sign of excessive speculation. Consequently, Working's T has a lower bound of unity and increases with this speculative pressure. Note, however, that as highlighted by Fattouh et al. (2013) and Boyd et al. (2018), "excessive" is to be understood in a technical and not a normative manner. An index value above one only indicates that there are more speculative positions in the market than necessary to offset the positions of hedgers, not that market functioning is fundamentally impaired by speculative activity.

In addition to these two speculation measures, we also consider a measure of hedging activity that is computed analogously to the total open interest share 
of speculators. But instead of using the positions of non-commercial traders, we now consider the positions of commercial traders. Hence, the total percentage share of hedgers, $H_{t}$, is defined as

$$
H_{t}=\frac{C L_{t}+C S_{t}+(1-\alpha) \cdot\left(N R L_{t}+N R S_{t}\right)}{2 \cdot M O I_{t}} \cdot 100
$$

Given these measures of speculation and hedging activity, $T_{t}, W_{t}$ and $H_{t}$, we are now able to analyze how both speculation and hedging affect the price discovery process. For this purpose the following linear regression model is estimated:

$$
P D_{t}=\beta_{0}+\beta_{1} S P E C_{t}+\beta_{2} V O L_{t}+\beta_{3} B A S I S_{t}+\beta_{4} F I N_{t}+\eta_{t}
$$

where $P D_{t}$ is one of the measures of the futures market's contribution to price discovery in period $t$, i.e. $C S_{f t}, I S_{f t}$ or $I L S_{f t}$. Similarly, $S P E C_{t}$ is a measure of the dominance of either trader type, i.e. $T_{t}, W_{t}$, or $H_{t} . V O L_{t}$ represents the trading volume, while $B A S I S_{t}$ denotes the spread between spot and futures prices. To control for the effects of the financialization period, a time dummy $F I N_{t}$ is included in the regression equation (16). It takes on the value of one for observations after 2003. During this time period new types of investors, most notably index traders, entered the commodity futures markets, while at the same time these markets experienced considerable price hikes and crashes (Irwin \& Sanders 2011, Domanski \& Heath 2007). Lastly, $\eta_{t}$ denotes random disturbances.

When investigating the impact of speculation (hedging) on the component share, positive values for $\beta_{1}$ indicate that speculators (hedgers) increase the futures market's relative avoidance of noise, i.e. speculators (hedgers) reduce the amount of noise in the futures market. Whereas a positive impact of speculation 
(hedging) on the information share implies either an increase of new information and/or a reduction of noise in the market. Finally, a positive impact on the information leadership share suggests that speculation (hedging) amplifies the futures market's ability to process new information.

\section{Data}

This study analyzes four agricultural commodity markets included in the CFTC's COT reports. We consider the markets for corn and soybeans, which are in terms of trading volume the two largest agricultural futures contracts. Moreover, we add two livestock contracts to our selection, namely the markets for live and feeder cattle. As these contracts are considerably smaller than those for corn and soybeans, our sample therefore covers both highly liquid and less liquid markets as well as grains and oilseeds and livestock contracts. All contracts are traded at the Chicago Board of Trade (CBOT), which is now part of the CME Group.

Daily data for spot and futures prices and futures trading volume are, for all of these commodities, retrieved from Thomson Reuters Datastream. Continuous futures price time series are obtained by switching to the nearest contract on the first day of each new trading month. Data on the open interest of the different trader types is taken from the CFTC's COT reports. Table 1 characterizes the selected futures contracts as well as the sample range for each market and provides descriptive statistics for prices, volume and the speculation variables. Data for corn and soybeans are available from 30 March 1982, while data for live and feeder cattle start from 3 January 1990 and 4 January 1993, respectively. All series end on 29 June 2018. However, for the later regression analysis, the sample is limited by the availability of CFTC COT report data.

Since seasonal patterns play a non-negligible role in agricultural commodity 
prices, we follow the deseasonalization procedure used e.g. by Dimpfl et al. (2017). Thereby, we regress the log spot and $\log$ futures price time series on a constant and eleven monthly dummy variables and use the residuals of this regression in the subsequent analysis.

\section{[ Table 1 about here. ]}

As shown in table 1, corn has the highest average trading volume with over 132 thousand futures contracts traded per day. Feeder cattle has the lowest average daily trading volume with roughly 5 thousand futures contracts. The feeder cattle market features on average the highest values for total speculation $\left(T_{t}\right)$ and excessive speculation $\left(W_{t}\right)$, while the soybeans market features the lowest. Conversely, total hedging $\left(H_{t}\right)$ is on average highest in the corn and soybeans market, while the feeder cattle market exhibits the lowest hedging levels.

[ Figure 1 about here. ]

Figure 1 displays the daily futures and spot prices for each of the four commodity contracts. In each panel, the futures price is indicated in black, while the spot price series is highlighted in gray. For all commodities, the graphs show a strong co-movement between spot prices and futures prices. Moreover, similar price developments can be observed for all commodities. Starting from moderate levels in the 1990s, the commodities experience rapid price increases with subsequent declines around the mid-2000s.

\section{[ Table 2 about here. ]}

As indicated above, using a VEC model requires that the time series considered are cointegrated, which in turn requires them to be integrated of order one. To test the price time series' order of integration, we employ two different 
stationarity tests, namely the tests of Dickey \& Fuller $(1979,1981)$ and Philipps \& Perron (1988), hereafter called the ADF test and PP test. Both tests are specified with a constant and a trend. The test results for the log series as well as $\log$ first differences are reported in table 2. The results of both tests show that the log series contain a unit root, while the log differences are stationary, indicating that the price time series are integrated of order one. In order to test for cointegration, Johansen's $(1988,1991)$ trace and eigenvalue tests are used. The results of the tests, also reported in table 2, show for all commodities that spot and futures prices are cointegrated as suggested by the cost-of-carry model. ${ }^{3}$

\section{Results and robustness}

Figure 2 shows how the information leadership shares of the futures markets (in percent) evolve over time. When the share is above $50 \%$, the futures market is dominant in the price discovery process. In this case, the futures market processes new information more quickly than the spot market. Alternating phases of price dominance by either market are observed for all commodities. However, the futures market generally dominates more often. In particular for the small markets, i.e. live and feeder cattle, a strong and persistent dominance of the futures market is visible most of the time. Table 3 reports the futures markets' information leadership shares when calculated in a static version based on estimating equation (5) for the full sample. Moreover, the table lists the results of the average value of the information leadership shares in the time-varying case of the rolling window estimation, and also the percentage of days where the futures market dominates. For all four commodities, it is observed that price discovery is generally dominated by the futures market.

3 Repeating the cointegration analysis after replacing additive outliers based on the test of Chang et al. (1988) did not yield any substantially different results. Therefore, the original data are used in the price discovery analysis. 
[ Figure 2 and table 3 about here. ]

To estimate the impact of speculation on price discovery, the price discovery time series are merged with the CFTC time series by taking the Tuesday observations. Table 4 reports the results of regressing the different price discovery shares of the futures market on total speculation $T$ as given in equation (16). ${ }^{4}$ For the component share, as outlined in section 2.3, a positive coefficient estimate of $T$ indicates that speculators reduce the amount of noise in the market. For the information share, a positive coefficient estimate implies that speculators reduce the level of noise and/or increase the ability of the futures market to process new information. Lastly, the coefficient estimate of speculation in the regression with the information leadership share represents the net effect that speculators exert on the futures market's price discovery function.

The results show that in two markets, corn and live cattle, speculation reduces the level of noise as indicated by the statistically significant positive coefficients of $T$ on $C S$. For all markets except the live cattle market, the impact of speculation on the information share is always positive and higher than the impact on the component share. This implies that speculators contribute to the processing of new information in these markets. However, the focus of this paper is the net effect of speculation on informational leadership, i.e. once the noise avoidance component has been removed from the information shares. This is given by the coefficient estimates of $T$ on $I L S$, which measure how strongly speculation contributes to the futures market's ability to process new information quickly and efficiently.

The estimated parameters are positive and highly statistically significant for two of the four markets, namely soybeans and feeder cattle. For corn and live cattle, total speculation has no statistically significant effect on the futures mar-

$4 \quad$ The results of stationarity tests of speculation and price discovery measures are provided in table 8 of the appendix. 
ket's price discovery function. This indicates that speculators increase the speed and efficiency at which the futures markets for soybeans and feeder cattle incorporate information.

[ Tables 4 to 6 about here. ]

Table 5 presents the results from repeating the earlier analysis, that is estimating equation (16) but regressing on excessive speculation as measured by Working's T, $W$. The findings are consistent with what has been reported above for total speculation. Again, the coefficient estimates of (excessive) speculation are positive and highly significant for the information leadership regressions for soybeans and feeder cattle. This implies in particular that what is typically deemed to be excessive speculation improves the futures market's ability to process new information. Note that with excessive speculation, the coefficient estimates are also significantly positive for live cattle, which were insignificant when considering the total level of speculation.

The results regarding the influence of hedging on price discovery are displayed in table 6 . We observe that for three of the four markets, hedgers do not reduce the level of noise in the market. Conversely, in the case of feeder cattle, hedgers significantly increase the level of noise. Similarly, we observe that in three out the four commodities, namely soybeans, live and feeder cattle, hedgers, unlike speculators, reduce the futures market's information processing ability. Intuitively, this can be explained by the idea that hedgers are interested in locking in future prices, while speculators intend to profit from expected price changes. Hence, speculative traders have, compared to hedgers, a greater incentive to gather and interpret new information about fundamentals. As discussed earlier, critics of the CFTC reports argue in particular that some of the positions classified as commercial are in fact hedging positions. Therefore, our results potentially underestimate the positive effects of speculation and the 
negative effects of hedgers on price discovery.

As explained above, the rolling window estimation required choosing a window size. To examine the sensitivity of our results to our initial choice, the earlier analysis is repeated using a variety of alternative window sizes, namely 200, 375 and 500 trading days. The former is arguably just large enough to have a sufficiently large number of observations to reliably estimate the VEC model. The latter two amount to one and a half and two trading years, respectively. The results from repeating the baseline speculation regressions with the alternative window sizes are reported in table 7.

\section{[ Table 7 about here. ]}

The findings are highly consistent across the different window sizes. For all commodities, total as well as excessive speculation are generally found to significantly reduce the amount of noise and increase the speed of information processing in the futures market. Conversely, in most of the cases, hedging activity is found to have a negative impact on the price discovery function of the futures market, in the sense that they hinder these markets from quickly incorporating new information. Note also that for all alternative window lengths, speculation in the corn market significantly improves the price discovery function of the futures market, which was not the case in the baseline regression.

\section{Conclusion}

While numerous studies have investigated whether price discovery primarily occurs in the spot market or the futures market, little work has been done to study the impact of futures speculation on the price discovery process. This paper has investigated how speculation affects the price discovery function of four agricultural commodity futures markets, namely the markets for corn, soy- 
beans, live and feeder cattle. As price discovery describes the timely and efficient incorporation of new information about fundamental values into prices, speculators can contribute to price discovery in two ways. First, they can reduce the amount of noise in the futures price. Second, speculators can add to the futures market's ability to process new information. For this purpose, a new measure of price discovery is used in this paper, namely the information leadership shares by Yan \& Zivot (2010) and Putninšs (2013). These metrics allow researchers to distinguish between the two sources of price discovery mentioned above. The time-varying information leadership shares of the futures markets are then regressed on alternative measures of speculative and hedging activity.

This paper finds evidence that speculation, both total and excessive, improves futures markets' price discovery function in both of the ways explained above. First, speculation reduces the level of noise incorporated in the futures prices considered in this analysis. Second, speculative activity increases the speed at which the futures prices reflect new information about changes in market fundamentals. Conversely, hedgers are, in our analysis, found to reduce futures markets' ability to process new information. Therefore, speculators, in contrast to hedgers, appear to be more informed and trade with a stronger focus on potential changes of fundamental values. The results of this paper imply that efforts by regulators to curb futures speculation could have adverse consequences for the price discovery process in commodity markets. 


\section{References}

Baillie, R. T., Booth, G. G., Tse, Y. \& Zabotina, T. (2002), 'Price discovery and common factor models', Journal of Financial Markets 5(3), 309-321.

Boyd, N. E., Harris, J. H. \& Li, B. (2018), 'An update on speculation and financialization in commodity markets', Journal of Commodity Markets 10, 91-104.

Chang, I., Tiao, G. C. \& Chen, C. (1988), 'Estimation of time series parameters in the presence of outliers', Technometrics 30(2), 193-204.

Dickey, D. A. \& Fuller, W. A. (1979), ‘Distribution of the estimators for autoregressive time series with a unit root', Journal of the American Statistical Association 74(366), 427-431.

Dickey, D. A. \& Fuller, W. A. (1981), 'Likelihood ratio statistics for autoregressive time series with a unit root', Econometrica 49(4), 1057-1072.

Dimpfl, T., Flad, M. \& Jung, R. C. (2017), 'Price discovery in agricultural commodity markets in the presence of futures speculation', Journal of Commodity Markets 5, 50-62.

Domanski, D. \& Heath, A. (2007), 'Financial investors and commodity markets', Bank for International Settlements Quarterly Review pp. 53-67.

Engel, C. (1996), 'The forward discount anomaly and the risk premium: A survey of recent evidence', Journal of Empirical Finance 3(2), 123-192.

Engle, R. F. \& Granger, C. W. J. (1987), ‘Co-integration and error correction: Representation, estimation, and testing', Econometrica 55(2), 251-276.

Fattouh, B., Kilian, L. \& Mahadeva, L. (2013), 'The role of speculation in oil markets: What have we learned so far?', The Energy Journal 34(3), 7-33. 
Fuller, W. A. (1996), Introduction to Statistical Time Series, 2nd edn, Wiley, New York.

Garbade, K. D. \& Silber, W. L. (1983), 'Price movements and price discovery in futures and cash markets', The Review of Economics and Statistics 65(2), 289297.

Gonzalo, J. \& Granger, C. (1995), 'Estimation of common long-memory components in cointegrated systems', Journal of Business $\mathcal{E}$ Economic Statistics 13(1), 27-35.

Grossman, S. J. (1977), 'The existence of futures markets, noisy rational expectations and informational externalities', The Review of Economic Studies 44(3), 431-449.

Hasbrouck, J. (1995), 'One security, many markets: Determining the contributions to price discovery', The Journal of Finance 50(4), 1175-1199.

Irwin, S. H. \& Sanders, D. R. (2011), 'Index funds, financialization, and commodity futures markets', Applied Economic Perspectives and Policy 33(1), 1-31.

Johansen, S. (1988), 'Statistical analysis of cointegration vectors', Journal of Economic Dynamics and Control 12(2-3), 231-254.

Johansen, S. (1991), 'Estimation and hypothesis testing of cointegration vectors in gaussian vector autoregressive models', Econometrica 59(6), 1551-1580.

Kaldor, N. (1940), 'A symposium on the theory of the forward market: A note on the theory of the forward market', The Review of Economic Studies 7(3), 196201.

Keynes, J. M. (1923), Some Aspects of Commodity Markets, The Collected Writings of John Maynard Keynes - Vol. XII, Cambridge University Press, chapter 3. Commodities. 
Lehmann, B. N. (2002), 'Some desiderata for the measurement of price discovery across markets', Journal of Financial Markets 5(3), 259-276.

Lien, D. \& Shrestha, K. (2009), 'A new information share measure', Journal of Futures Markets 29(4), 377-395.

MacKinnon, J. G. (1994), 'Approximate asymptotic distribution functions for unit-root and cointegration tests', Journal of Business $\mathcal{E}$ Economic Statistics 12(2), 167-176.

MacKinnon, J. G., Haug, A. A. \& Michelis, L. (1999), ‘Numerical distribution functions of likelihood ratio tests for cointegration', Journal of Applied Econometrics 14(5), 563-577.

Manera, M., Nicolini, M. \& Vignati, I. (2016), 'Modelling futures price volatility in energy markets: Is there a role for financial speculation?', Energy Economics $53,220-229$.

Philipps, P. C. B. \& Perron, P. (1988), 'Testing for a unit root in time series regression', Biometrika 75(2), 335-346.

Putniňš, T. J. (2013), 'What do price discovery metrics really measure?', Journal of Empirical Finance 23, 68-83.

Rutledge, D. J. S. (1977), 'Estimation of hedging and speculative positions in futures markets: An alternative approach', Food Research Institute Studies 16(3), 205-211.

Sanders, D. R., Boris, K. \& Manfredo, M. (2004), 'Hedgers, funds, and small speculators in the energy futures markets: an analysis of the CFTC's commitments of traders reports', Energy Economics 26(3), 425-445. 
Sanders, D. R., Irwin, S. H. \& Merrin, R. P. (2010), 'The adequacy of speculation in agricultural futures markets: Too much of a good thing?', Applied Economic Perspectives and Policy 32(1), 77-94.

Schwarz, G. (1978), 'Estimating the dimension of a model', The Annals of Statistics 6(2), 461-464.

Schwarz, T. V. \& Szakmary, A. C. (1994), ‘Price discovery in petroleum markets: Arbitrage, cointegration, and the time interval of analysis', Journal of Futures Markets 14(2), 147-167.

Stock, J. H. \& Watson, M. W. (1988), 'Testing for common trends', Journal of the American Statistical Association 83(404), 1097-1107.

Working, H. (1960), 'Speculation on hedging markets', Food Research Institute Studies 1(2), 185-220.

Yan, B. \& Zivot, E. (2010), 'A structural analysis of price discovery measures', Journal of Financial Markets 13(1), 1-19.

Yang, J., Bessler, D. A. \& Leatham, D. J. (2001), 'Asset storability and price discovery in commodity futures markets: A new look', Journal of Futures Markets 21(3), 279-300.

Yang, J. \& Leatham, D. J. (1999), 'Price discovery in wheat futures markets', Journal of Agricultural and Applied Economics 31(2), 359-370.

Zapata, H. O. \& Fortenbery, T. R. (1996), 'Stochastic interest rates and price discovery in selected commodity markets', Applied Economic Perspectives and Policy 18(4), 643-654.

Zivot, E. (2000), 'Cointegration and forward and spot exchange rate regressions', Journal of International Money and Finance 19(6), 785-812. 
(a) Corn

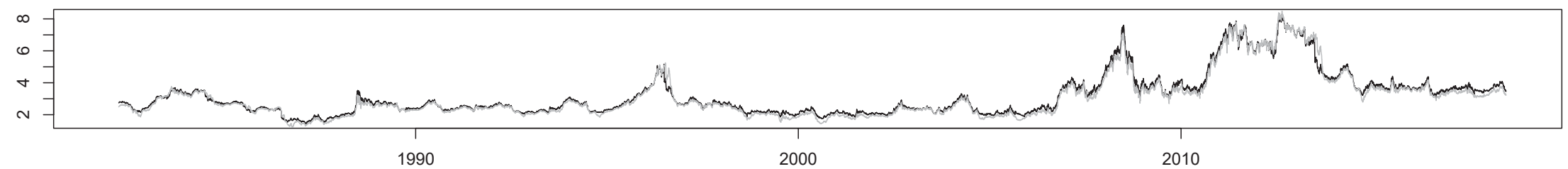

(b) Soybeans

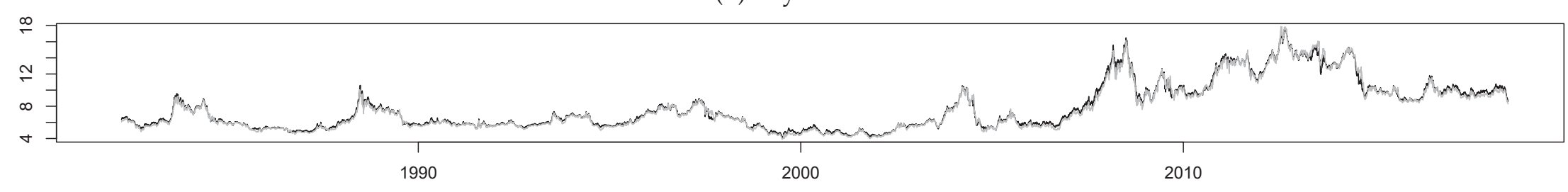

(c) Live Cattle

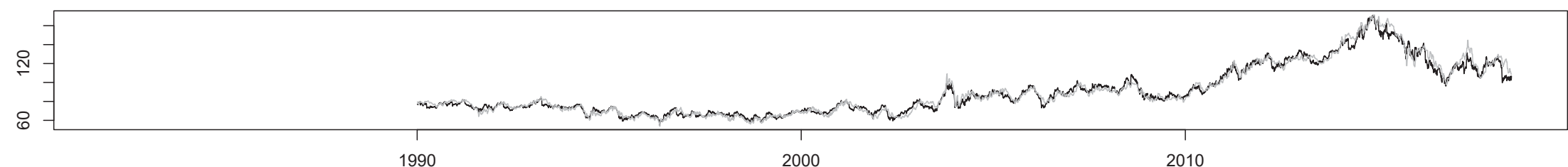

(d) Feeder Cattle

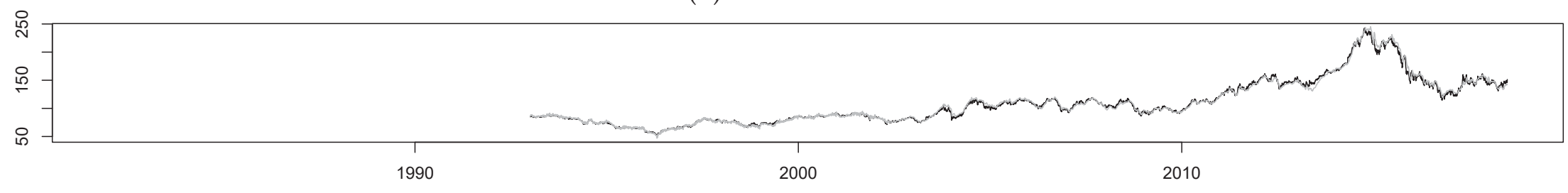

Figure 1: Futures and Spot Prices

Note: Futures prices are depicted using black lines, spot prices are displayed in gray. 
(a) Corn

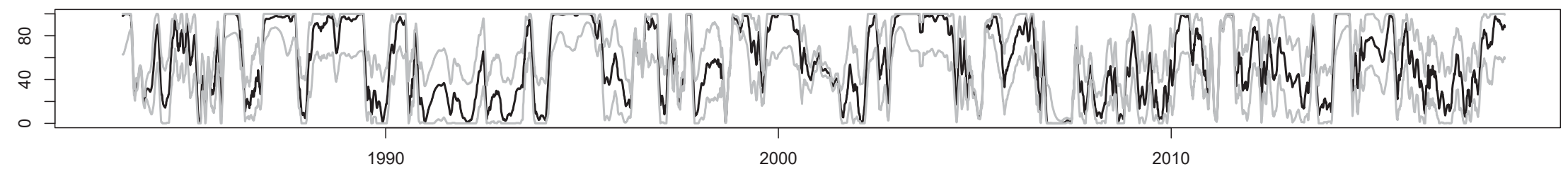

(b) Soybeans

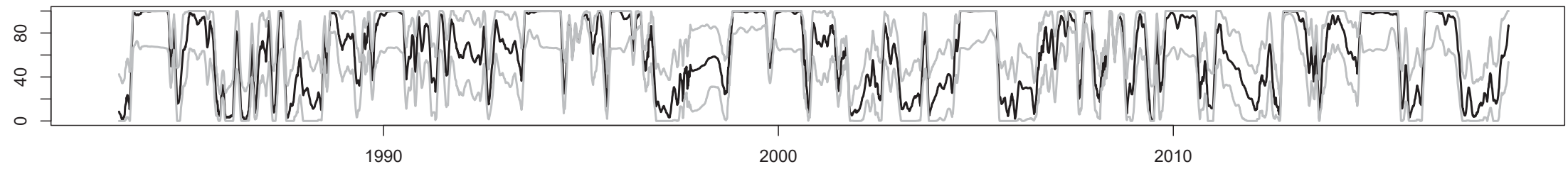

N

(c) Live Cattle

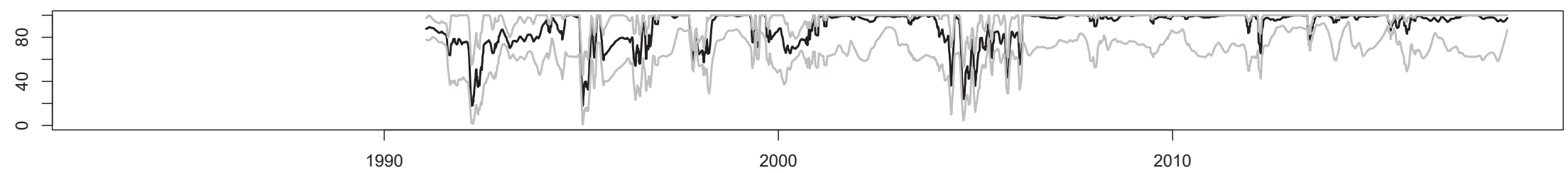

(d) Feeder Cattle

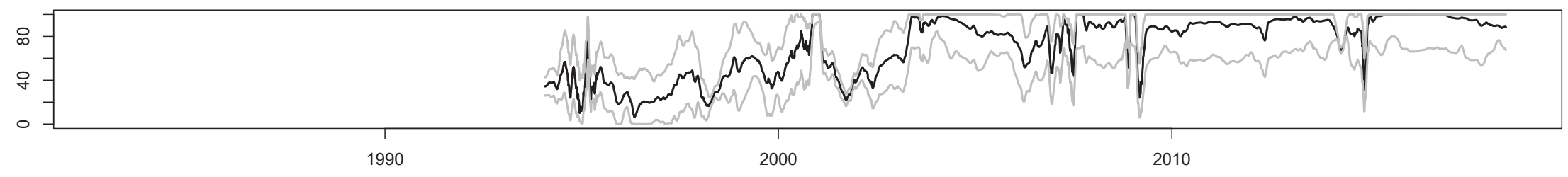

Figure 2: Futures Market Information Leadership Shares (Monthly Moving Average)

Note: Futures markets information leadership shares are depicted using black lines. Confidence intervals based on nonparametrically bootstrapped standard errors are displayed in gray. For each rolling window regression, 1000 bootstrap samples are generated from blockwise resampling. 
Table 1: Descriptive Statistics

\begin{tabular}{|c|c|c|c|c|c|c|}
\hline Variable & Min. & Mean & Max. & St.dev. & Skew. & Kurt. \\
\hline \multicolumn{7}{|c|}{ CME No.2 Yellow Corn (5,000 bu), 30 Mar. 1982 - 29 June 2018} \\
\hline Futures & -0.19 & 0.00 & 0.13 & 0.02 & 0.19 & 11.50 \\
\hline Spot & -0.12 & 0.00 & 0.11 & 0.02 & -0.08 & 7.36 \\
\hline Volume & 0.19 & 132.76 & 1090.83 & 133.35 & 1.71 & 6.30 \\
\hline Speculation & 19.99 & 27.11 & 39.98 & 3.66 & 0.93 & 3.82 \\
\hline Working's T & 1.09 & 1.18 & 1.39 & 0.06 & 0.97 & 3.24 \\
\hline Hedging & 48.74 & 61.38 & 72.97 & 5.46 & -0.40 & 2.37 \\
\hline
\end{tabular}

CME No.1 Yellow Soybeans (5,000 bu), 30 Mar. 1982 - 29 June 2018

\begin{tabular}{lrrrrrr} 
Futures & -0.14 & 0.00 & 0.10 & 0.01 & -0.23 & 7.57 \\
Spot & -0.17 & 0.00 & 0.11 & 0.02 & -0.49 & 8.97 \\
Volume & 0.10 & 86.78 & 804.24 & 83.82 & 1.65 & 6.54 \\
Speculation & 19.35 & 26.71 & 37.10 & 2.98 & 0.84 & 3.69 \\
Working's T & 1.07 & 1.16 & 1.35 & 0.05 & 0.76 & 3.57 \\
Hedging & 48.49 & 60.15 & 70.05 & 3.64 & -0.24 & 2.90 \\
\hline
\end{tabular}

CME Live Cattle (40,000 lbs), 03 Jan. 1990 - 29 June 2018

\begin{tabular}{lrrrrrr} 
Futures & 0.09 & 0.00 & 0.10 & 0.01 & -0.06 & 8.15 \\
Spot & -0.09 & 0.00 & 0.07 & 0.01 & 0.18 & 10.82 \\
Volume & 0.00 & 29.85 & 206.30 & 20.95 & 1.44 & 5.90 \\
Speculation & 21.42 & 31.46 & 44.09 & 3.69 & 0.06 & 2.79 \\
Working's T & 1.11 & 1.23 & 1.47 & 0.05 & 0.99 & 4.69 \\
Hedging & 43.73 & 56.82 & 70.57 & 5.00 & 0.19 & 2.51 \\
\hline
\end{tabular}

CME Feeder Cattle (50,000 lbs), 04 Jan. 1993 - 29 June 2018

\begin{tabular}{lrrrrrr} 
Futures & -0.06 & 0.00 & 0.06 & 0.01 & -0.12 & 5.29 \\
Spot & -0.08 & 0.00 & 0.09 & 0.01 & -0.02 & 8.91 \\
Volume & 0.00 & 4.99 & 29.67 & 3.82 & 1.73 & 6.59 \\
Speculation & 33.76 & 46.57 & 61.71 & 4.04 & 0.10 & 3.13 \\
Working's T & 1.27 & 1.50 & 1.89 & 0.09 & 0.47 & 4.04 \\
Hedging & 29.42 & 43.15 & 56.41 & 5.07 & 0.31 & 2.73 \\
\hline
\end{tabular}

Note: The first two rows of each commodity panel report the summary statistics of futures and spot log returns. Trading volume is reported in thousands. The speculation, hedging and Working's T variables are computed based on CFTC data as outlined in Section 2. 
Table 2: Unit Root and Cointegration Tests

\begin{tabular}{|c|c|c|c|c|c|}
\hline \multirow[b]{2}{*}{ Commodity } & \multirow[b]{2}{*}{ Variable } & \multicolumn{2}{|c|}{ ADF test } & \multicolumn{2}{|c|}{ PP test } \\
\hline & & Logs & Log returns & Logs & Log returns \\
\hline \multirow[t]{2}{*}{ Corn } & Futures & -2.75 & $-55.25^{* * *}$ & -2.75 & $-91.52^{* * *}$ \\
\hline & Spot & -2.67 & $-95.28^{* * *}$ & -2.67 & $-95.28^{* * *}$ \\
\hline \multirow[t]{2}{*}{ Soybeans } & Futures & -2.76 & $-94.50^{* * *}$ & -2.74 & $-94.50^{* * *}$ \\
\hline & Spot & -2.72 & $-68.42^{* * *}$ & -2.74 & $-98.93^{* * *}$ \\
\hline \multirow[t]{2}{*}{ Live Cattle } & Futures & $-3.26^{*}$ & $-58.68^{* * *}$ & $-3.22 *$ & $-81.31^{* * *}$ \\
\hline & Spot & -2.72 & $-31.22^{* * *}$ & $-3.24^{*}$ & $-83.03^{* * *}$ \\
\hline \multirow[t]{3}{*}{ Feeder Cattle } & Futures & -3.08 & $-54.74^{* * *}$ & -2.98 & $-74.03^{* * *}$ \\
\hline & Spot & -2.70 & $-16.59^{* * *}$ & -2.69 & $-124.19^{* * *}$ \\
\hline & & \multicolumn{4}{|c|}{ Johansen tests } \\
\hline \multicolumn{2}{|l|}{ Commodity } & \multicolumn{2}{|c|}{ Null hypothesis } & Trace & Eigenvalue \\
\hline \multirow[t]{2}{*}{ Corn } & & \multicolumn{2}{|c|}{$H_{0}: r=0$} & $90.38^{* * *}$ & $84.91^{* * *}$ \\
\hline & & \multicolumn{2}{|c|}{$H_{0}: r=1$} & 5.46 & 5.46 \\
\hline \multirow[t]{2}{*}{ Soybeans } & & \multicolumn{2}{|c|}{$H_{0}: r=0$} & $214.85^{* * *}$ & $210.13^{* * *}$ \\
\hline & & \multicolumn{2}{|c|}{$H_{0}: r=1$} & 4.72 & 4.72 \\
\hline \multirow[t]{2}{*}{ Live Cattle } & & \multicolumn{2}{|c|}{$H_{0}: r=0$} & $413.60^{* * *}$ & $410.27^{* * *}$ \\
\hline & & \multicolumn{2}{|c|}{$H_{0}: r=1$} & 3.33 & 3.33 \\
\hline \multirow[t]{2}{*}{ Feeder Cattle } & & \multicolumn{2}{|c|}{$H_{0}: r=0$} & $526.52^{* * *}$ & $525.15^{* * *}$ \\
\hline & & \multicolumn{2}{|c|}{$H_{0}: r=1$} & 1.37 & 1.37 \\
\hline
\end{tabular}

Note: The table reports for log prices and log returns the critical values of the ADF and the PP test (both including a constant and a trend) as computed by Fuller (1996), while the optimum lag-lengths have been determined using the Bayesian-Schwarz information criterion (1978). Moreover, the table displays for log prices the critical values of the Johansen $(1988,1991)$ trace and eigenvalue tests as computed by MacKinnon et al. (1999). The null hypothesis $r=0$ tests for no cointegration, while the null hypothesis $r=1$ tests for a cointegration rank of one. Statistical significance is reported as * for $p<0.1{ }^{* *}$ for $p<0.05$ and $^{* * *}$ for $p<0.01$. 
Table 3: Futures Market Information Leadership Shares

\begin{tabular}{lccc}
\hline Commodity & Full Sample Static & Average Time-Varying & Relative Dominance \\
\hline Corn & 87.43 & 55.94 & 54.12 \\
Soybeans & 55.04 & 62.00 & 63.14 \\
Live Cattle & 99.84 & 89.61 & 95.56 \\
Feeder Cattle & 82.21 & 71.23 & 73.12 \\
\hline
\end{tabular}

Note: The second column reports the futures market's information leadership shares based on the full-sample VEC model. Values above 50 indicate that the futures market is dominant in the price discovery process. The third column displays the average information leadership shares of the timevarying VEC model. For the same regressions, the rightmost column shows the percentage shares of days where the futures market is dominant. Values greater than 50 indicate that the futures market dominates more often than the spot market. 
Table 4: Results of Regressions with Total Speculation $(T)$

\begin{tabular}{|c|c|c|c|c|c|c|c|c|c|c|c|c|}
\hline & \multicolumn{3}{|c|}{ Corn } & \multicolumn{3}{|c|}{ Soybeans } & \multicolumn{3}{|c|}{ Live Cattle } & \multicolumn{3}{|c|}{ Feeder Cattle } \\
\hline & CS & IS & ILS & CS & IS & ILS & CS & IS & ILS & CS & IS & ILS \\
\hline$T$ & $\begin{array}{l}2.054^{* * *} \\
(0.205)\end{array}$ & $\begin{array}{l}2.263^{* * *} \\
(0.205)\end{array}$ & $\begin{array}{c}-0.283 \\
(0.317)\end{array}$ & $\begin{array}{c}-0.560^{* *} \\
(0.285)\end{array}$ & $\begin{array}{c}0.646^{* *} \\
(0.329)\end{array}$ & $\begin{array}{l}2.444^{* * *} \\
(0.340)\end{array}$ & $\begin{array}{l}0.425^{* * *} \\
(0.070)\end{array}$ & $\begin{array}{l}0.203^{* * *} \\
(0.034)\end{array}$ & $\begin{array}{c}0.182 \\
(0.132)\end{array}$ & $\begin{array}{c}0.134 \\
(0.113)\end{array}$ & $\begin{array}{l}0.301^{* * *} \\
(0.113)\end{array}$ & $\begin{array}{l}0.549^{* * *} \\
(0.141)\end{array}$ \\
\hline$V O L$ & $\begin{array}{c}-0.023^{* * *} \\
(0.007)\end{array}$ & $\begin{array}{c}-0.021^{* * *} \\
(0.006)\end{array}$ & $\begin{array}{c}0.002 \\
(0.009)\end{array}$ & $\begin{array}{c}0.022^{* *} \\
(0.010)\end{array}$ & $\begin{array}{c}0.009 \\
(0.010)\end{array}$ & $\begin{array}{r}-0.025^{*} \\
(0.014)\end{array}$ & $\begin{array}{c}0.015 \\
(0.015)\end{array}$ & $\begin{array}{c}0.012 \\
(0.008)\end{array}$ & $\begin{array}{l}0.168^{* * *} \\
(0.040)\end{array}$ & $\begin{array}{c}0.386^{* *} \\
(0.161)\end{array}$ & $\begin{array}{l}0.437^{* * *} \\
(0.126)\end{array}$ & $\begin{array}{l}0.527^{* * *} \\
(0.109)\end{array}$ \\
\hline$B A S I S$ & $\begin{array}{c}4.755 \\
(3.912)\end{array}$ & $\begin{array}{c}-5.924 \\
(5.119)\end{array}$ & $\begin{array}{c}-17.590^{* * *} \\
(5.803)\end{array}$ & $\begin{array}{c}-0.907 \\
(3.069)\end{array}$ & $\begin{array}{l}5.463 \\
(3.861)\end{array}$ & $\begin{array}{l}12.779^{* * *} \\
(4.147)\end{array}$ & $\begin{array}{c}0.089^{*} \\
(0.053)\end{array}$ & $\begin{array}{l}0.106^{* * *} \\
(0.025)\end{array}$ & $\begin{array}{c}0.170^{* *} \\
(0.078)\end{array}$ & $\begin{array}{c}-0.085 \\
(0.121)\end{array}$ & $\begin{array}{r}-0.182^{*} \\
(0.097)\end{array}$ & $\begin{array}{c}-0.349^{* * *} \\
(0.123)\end{array}$ \\
\hline Cons. & $\begin{array}{l}11.772^{* *} \\
(5.583)\end{array}$ & $\begin{array}{l}17.411^{* * *} \\
(5.650)\end{array}$ & $\begin{array}{l}77.454^{* * *} \\
(8.527)\end{array}$ & $\begin{array}{l}69.627^{* * *} \\
(7.799)\end{array}$ & $\begin{array}{l}44.329^{* * *} \\
(9.036)\end{array}$ & $\begin{array}{c}-5.912 \\
(9.464)\end{array}$ & $\begin{array}{l}72.331^{* * *} \\
(2.256)\end{array}$ & $\begin{array}{l}88.283^{* * *} \\
(1.215)\end{array}$ & $\begin{array}{l}79.011^{* * *} \\
(3.962)\end{array}$ & $\begin{array}{l}77.047^{* * *} \\
(5.424)\end{array}$ & $\begin{array}{l}66.289^{* * *} \\
(5.464)\end{array}$ & $\begin{array}{l}19.886^{* * *} \\
(6.474)\end{array}$ \\
\hline $\bar{R}^{2}$ & 0.119 & 0.198 & 0.046 & 0.008 & 0.004 & 0.038 & 0.066 & 0.087 & 0.054 & 0.136 & 0.029 & 0.559 \\
\hline
\end{tabular}

Note: The table reports the results of regressing the following equation: $P D_{t}=\beta_{0}+\beta_{1} T_{t}+\beta_{2} V O L_{t}+\beta_{3} B A S I S_{t}+\beta_{4} F I N_{t}+\eta_{t}$, where $P D$ is either the component share $(C S)$, the information share $(I S)$ or the information leadership share $(I L S)$, which have been computed using a window size of 250 trading days. T describes the level of total speculation, VOL and BASIS refer to trading volume and the basis spread, and FIN denotes the financialization dummy. White-corrected heteroscedasticity-robust standard errors are provided in parentheses. Statistical significance is reported as * for $p<0.1,{ }^{* *}$ for $p<0.05$ and ${ }^{* * *}$ for $p<0.01$. 
Table 5: Results of Regressions with Excessive Speculation $(W)$

\begin{tabular}{|c|c|c|c|c|c|c|c|c|c|c|c|c|}
\hline & \multicolumn{3}{|c|}{ Corn } & \multicolumn{3}{|c|}{ Soybeans } & \multicolumn{3}{|c|}{ Live Cattle } & \multicolumn{3}{|c|}{ Feeder Cattle } \\
\hline & CS & IS & ILS & CS & IS & ILS & CS & IS & ILS & CS & IS & ILS \\
\hline$W$ & $\begin{array}{c}68.297^{* * *} \\
(13.105)\end{array}$ & $\begin{array}{c}\text { 68.771 } \\
(12.940)\end{array}$ & $\begin{array}{c}-27.460 \\
(17.632)\end{array}$ & $\begin{array}{l}73.088^{* * *} \\
(14.847)\end{array}$ & $\begin{array}{l}108.647^{* * *} \\
(16.718)\end{array}$ & $\begin{array}{l}78.300^{* * *} \\
(21.251)\end{array}$ & $\begin{array}{c}5.645 \\
(4.206)\end{array}$ & $\begin{array}{l}6.775^{* * * *} \\
(2.043)\end{array}$ & $\begin{array}{l}20.346^{* *} \\
(8.285)\end{array}$ & $\begin{array}{l}21.544^{* * *} \\
(5.302)\end{array}$ & $\begin{array}{l}27.017^{* * *} \\
(5.037)\end{array}$ & $\begin{array}{l}44.168^{* * *} \\
(6.149)\end{array}$ \\
\hline$V O L$ & $\begin{array}{c}-0.019^{* *} \\
(0.008)\end{array}$ & $\begin{array}{c}-0.016^{* *} \\
(0.007)\end{array}$ & $\begin{array}{c}0.003 \\
(0.009)\end{array}$ & $\begin{array}{c}0.023^{* *} \\
(0.010)\end{array}$ & $\begin{array}{c}0.011 \\
(0.010)\end{array}$ & $\begin{array}{r}-0.025^{*} \\
(0.015)\end{array}$ & $\begin{array}{l}0.040^{* * *} \\
(0.014)\end{array}$ & $\begin{array}{l}0.022^{* * *} \\
(0.007)\end{array}$ & $\begin{array}{l}0.169^{* * *} \\
(0.038)\end{array}$ & $\begin{array}{c}0.262^{*} \\
(0.159)\end{array}$ & $\begin{array}{c}0.284^{* *} \\
(0.128)\end{array}$ & $\begin{array}{c}0.277^{* *} \\
(0.117)\end{array}$ \\
\hline$B A S I S$ & $\begin{array}{c}-0.404 \\
(4.015)\end{array}$ & $\begin{array}{c}-12.056^{* *} \\
(5.251)\end{array}$ & $\begin{array}{c}-18.130^{* * *} \\
(5.676)\end{array}$ & $\begin{array}{l}4.711 \\
(3.113)\end{array}$ & $\begin{array}{c}7.777^{* *} \\
(3.677)\end{array}$ & $\begin{array}{c}6.365 \\
(4.019)\end{array}$ & $\begin{array}{c}0.039 \\
(0.055)\end{array}$ & $\begin{array}{l}0.080^{* * *} \\
(0.026)\end{array}$ & $\begin{array}{c}0.140^{*} \\
(0.078)\end{array}$ & $\begin{array}{c}-0.095 \\
(0.121)\end{array}$ & $\begin{array}{r}-0.184^{*} \\
(0.099)\end{array}$ & $\begin{array}{c}-0.348^{* * *} \\
(0.124)\end{array}$ \\
\hline$F I N$ & $\begin{array}{c}-10.102^{* * *} \\
(2.058)\end{array}$ & $\begin{array}{c}-19.238^{* * *} \\
(2.190)\end{array}$ & $\begin{array}{c}-15.143^{* * *} \\
(2.834)\end{array}$ & $\begin{array}{c}0.038 \\
(1.932)\end{array}$ & $\begin{array}{c}1.089 \\
(2.270)\end{array}$ & $\begin{array}{r}5.038^{*} \\
(2.794)\end{array}$ & $\begin{array}{l}2.367^{* * *} \\
(0.697)\end{array}$ & $\begin{array}{l}2.643^{* * *} \\
(0.471)\end{array}$ & $\begin{array}{c}1.304 \\
(1.518)\end{array}$ & $\begin{array}{c}-15.287^{* * *} \\
(1.198)\end{array}$ & $\begin{array}{c}1.278 \\
(1.223)\end{array}$ & $\begin{array}{l}37.054^{* * *} \\
(1.373)\end{array}$ \\
\hline Cons. & $\begin{array}{c}-13.748 \\
(15.302)\end{array}$ & $\begin{array}{l}-3.148 \\
(15.255)\end{array}$ & $\begin{array}{l}102.042^{* * *} \\
(20.553)\end{array}$ & $\begin{array}{r}-30.577^{*} \\
(17.385)\end{array}$ & $\begin{array}{c}-64.886^{* * *} \\
(19.348)\end{array}$ & $\begin{array}{c}-31.416 \\
(24.952)\end{array}$ & $\begin{array}{l}78.498^{* * *} \\
(5.139)\end{array}$ & $\begin{array}{l}86.289^{* * *} \\
(2.511)\end{array}$ & $\begin{array}{l}59.993^{* * *} \\
(10.069)\end{array}$ & $\begin{array}{l}52.188^{* * *} \\
(7.785)\end{array}$ & $\begin{array}{l}41.363^{* * *} \\
(7.456)\end{array}$ & $\begin{array}{c}-18.229^{* *} \\
(8.688)\end{array}$ \\
\hline $\bar{R}^{2}$ & 0.071 & 0.144 & 0.047 & 0.024 & 0.033 & 0.013 & 0.040 & 0.077 & 0.056 & 0.146 & 0.042 & 0.571 \\
\hline
\end{tabular}

Note: The table reports the results of regressing the following equation: $P D_{t}=\beta_{0}+\beta_{1} W_{t}+\beta_{2} V O L_{t}+\beta_{3} B A S I S_{t}+\beta_{4} F I N_{t}+\eta_{t}$, where $P D$ is either the component share $(C S)$, the information share $(I S)$ or the information leadership share $(I L S)$, which have been computed using a window size of 250 trading days. $W$ stands for the Working's T index, VOL and BASIS refer to trading volume and the basis spread, and FIN denotes the financialization dummy. White-corrected heteroscedasticity-robust standard errors are provided in parentheses. Statistical significance is reported as ${ }^{*}$ for $p<0.1,{ }^{* *}$ for $p<0.05$ and $* * *$ for $p<0.01$ 
Table 6: Results of Regressions with Total Hedging $(H)$

\begin{tabular}{|c|c|c|c|c|c|c|c|c|c|c|c|c|}
\hline & \multicolumn{3}{|c|}{ Corn } & \multicolumn{3}{|c|}{ Soybeans } & \multicolumn{3}{|c|}{ Live Cattle } & \multicolumn{3}{|c|}{ Feeder Cattle } \\
\hline & CS & IS & ILS & CS & IS & ILS & CS & IS & ILS & CS & IS & ILS \\
\hline$H$ & $\begin{array}{c}-0.309 \\
(0.193)\end{array}$ & $\begin{array}{r}-0.314^{*} \\
(0.190)\end{array}$ & $\begin{array}{c}0.402^{*} \\
(0.242)\end{array}$ & $\begin{array}{c}0.321 \\
(0.213)\end{array}$ & $\begin{array}{c}-0.686^{* * *} \\
(0.247)\end{array}$ & $\begin{array}{c}-2.092^{* * *} \\
(0.290)\end{array}$ & $\begin{array}{c}-0.013 \\
(0.064)\end{array}$ & $\begin{array}{c}-0.289^{* * *} \\
(0.034)\end{array}$ & $\begin{array}{c}-1.199^{* * *} \\
(0.116)\end{array}$ & $\begin{array}{c}-0.634^{* * *} \\
(0.115)\end{array}$ & $\begin{array}{c}-0.979^{* * *} \\
(0.129)\end{array}$ & $\begin{array}{c}-1.413^{* * *} \\
(0.151)\end{array}$ \\
\hline$V O L$ & $\begin{array}{c}-0.019^{* *} \\
(0.008)\end{array}$ & $\begin{array}{c}-0.016^{* *} \\
(0.007)\end{array}$ & $\begin{array}{c}0.007 \\
(0.010)\end{array}$ & $\begin{array}{c}0.025^{* *} \\
(0.011)\end{array}$ & $\begin{array}{c}0.003 \\
(0.011)\end{array}$ & $\begin{array}{c}-0.045^{* * *} \\
(0.015)\end{array}$ & $\begin{array}{l}0.042^{* * *} \\
(0.015)\end{array}$ & $\begin{array}{c}0.001 \\
(0.008)\end{array}$ & $\begin{array}{c}0.076^{* *} \\
(0.037)\end{array}$ & $\begin{array}{c}0.124 \\
(0.161)\end{array}$ & $\begin{array}{c}0.034 \\
(0.135)\end{array}$ & $\begin{array}{c}-0.054 \\
(0.127)\end{array}$ \\
\hline$B A S I S$ & $\begin{array}{c}-4.071 \\
(4.061)\end{array}$ & $\begin{array}{c}-15.740^{* * *} \\
(5.279)\end{array}$ & $\begin{array}{c}-17.610^{* * *} \\
(5.670)\end{array}$ & $\begin{array}{c}0.766 \\
(2.926)\end{array}$ & $\begin{array}{c}4.138 \\
(3.658)\end{array}$ & $\begin{array}{r}6.800^{*} \\
(3.859)\end{array}$ & $\begin{array}{c}0.043 \\
(0.054)\end{array}$ & $\begin{array}{l}0.092^{* * *} \\
(0.025)\end{array}$ & $\begin{array}{c}0.183^{* *} \\
(0.075)\end{array}$ & $\begin{array}{c}-0.142 \\
(0.122)\end{array}$ & $\begin{array}{c}-0.262^{* * *} \\
(0.099)\end{array}$ & $\begin{array}{c}-0.456^{* * *} \\
(0.121)\end{array}$ \\
\hline$F I N$ & $\begin{array}{c}-10.440^{* * *} \\
(2.149)\end{array}$ & $\begin{array}{c}-19.587^{* * *} \\
(2.365)\end{array}$ & $\begin{array}{c}-13.989^{* * *} \\
(2.985)\end{array}$ & $\begin{array}{c}1.004 \\
(1.888)\end{array}$ & $\begin{array}{c}1.347 \\
(2.270)\end{array}$ & $\begin{array}{c}3.607 \\
(2.779)\end{array}$ & $\begin{array}{l}2.342^{* * *} \\
(0.724)\end{array}$ & $\begin{array}{l}1.458^{* * *} \\
(0.417)\end{array}$ & $\begin{array}{c}-3.660^{* *} \\
(1.596)\end{array}$ & $\begin{array}{c}-17.295^{* * *} \\
(1.314)\end{array}$ & $\begin{array}{c}-2.065 \\
(1.314)\end{array}$ & $\begin{array}{l}32.426^{* * *} \\
(1.594)\end{array}$ \\
\hline Cons. & $\begin{array}{l}86.533^{* * *} \\
(12.991)\end{array}$ & $\begin{array}{c}97.992^{* * *} \\
(12.674)\end{array}$ & $\begin{array}{l}43.255^{* * *} \\
(16.393)\end{array}$ & $\begin{array}{l}34.709^{* * *} \\
(13.210)\end{array}$ & $\begin{array}{l}104.082^{* * *} \\
(15.468)\end{array}$ & $\begin{array}{l}189.142^{* * *} \\
(18.112)\end{array}$ & $\begin{array}{l}86.094^{* * *} \\
(3.934)\end{array}$ & $\begin{array}{c}112.332^{* * *} \\
(1.944)\end{array}$ & $\begin{array}{c}158.764^{* * *} \\
(6.992)\end{array}$ & $\begin{array}{c}113.718^{* * *} \\
(5.422)\end{array}$ & $\begin{array}{c}127.344^{* * *} \\
(5.996)\end{array}$ & $\begin{array}{c}113.389^{* * *} \\
(7.558)\end{array}$ \\
\hline $\bar{R}^{2}$ & 0.049 & 0.125 & 0.048 & 0.006 & 0.007 & 0.043 & 0.039 & 0.102 & 0.113 & 0.155 & 0.075 & 0.592 \\
\hline
\end{tabular}

Note: The table reports the results of regressing the following equation: $P D_{t}=\beta_{0}+\beta_{1} H_{t}+\beta_{2} V O L_{t}+\beta_{3} B A S I S_{t}+\beta_{4} F I N_{t}+\eta_{t}$, where $P D$ is either the component share $(C S)$, the information share $(I S)$ or the information leadership share $(I L S)$, which have been computed using a window size of 250 trading days. $H$ describes the level of total hedging, VOL and BASIS refer to trading volume and the basis spread, and FIN denotes the financialization dummy. White-corrected heteroscedasticity-robust standard errors are provided in parentheses. Statistical significance is reported as ${ }^{*}$ for $p<0.1$, ${ }^{* *}$ for $p<0.05$ and $* * *$ for $p<0.01$ 
Table 7: Results of Robustness Exercise

\begin{tabular}{|c|c|c|c|c|c|c|c|c|c|c|c|c|}
\hline & \multicolumn{3}{|c|}{ Corn } & \multicolumn{3}{|c|}{ Soybeans } & \multicolumn{3}{|c|}{ Live Cattle } & \multicolumn{3}{|c|}{ Feeder Cattle } \\
\hline & CS & IS & ILS & CS & IS & ILS & CS & IS & ILS & CS & IS & ILS \\
\hline$T(200)$ & $\begin{array}{l}1.557^{* * *} \\
(0.240)\end{array}$ & $\begin{array}{l}2.174^{* * *} \\
(0.220)\end{array}$ & $\begin{array}{c}0.688^{* *} \\
(0.309)\end{array}$ & $\begin{array}{c}0.492^{*} \\
(0.274)\end{array}$ & $\begin{array}{l}1.720^{* * *} \\
(0.367)\end{array}$ & $\begin{array}{l}1.995^{* * *} \\
(0.422)\end{array}$ & $\begin{array}{l}0.326^{* * *} \\
(0.074)\end{array}$ & $\begin{array}{l}0.135^{* * *} \\
(0.039)\end{array}$ & $\begin{array}{c}0.292^{* *} \\
(0.138)\end{array}$ & $\begin{array}{r}-0.203^{*} \\
(0.109)\end{array}$ & $\begin{array}{c}0.012 \\
(0.112)\end{array}$ & $\begin{array}{l}0.631^{\text {*** }} \\
(0.148)\end{array}$ \\
\hline$T(375)$ & $\begin{array}{l}1.980^{* * *} \\
(0.182)\end{array}$ & $\begin{array}{l}2.755^{* * *} \\
(0.204)\end{array}$ & $\begin{array}{l}1.467^{* * *} \\
(0.289)\end{array}$ & $\begin{array}{c}-0.134 \\
(0.275)\end{array}$ & $\begin{array}{c}0.243 \\
(0.282)\end{array}$ & $\begin{array}{l}1.330^{* * *} \\
(0.417)\end{array}$ & $\begin{array}{l}0.470^{* * *} \\
(0.064)\end{array}$ & $\begin{array}{l}0.243^{* * *} \\
(0.032)\end{array}$ & $\begin{array}{l}0.268^{* *} \\
(0.126)\end{array}$ & $\begin{array}{l}0.508^{* * *} \\
(0.101)\end{array}$ & $\begin{array}{l}0.574^{* * *} \\
(0.100)\end{array}$ & $\begin{array}{c}0.166 \\
(0.120)\end{array}$ \\
\hline$T(500)$ & $\begin{array}{l}1.666^{* * *} \\
(0.176)\end{array}$ & $\begin{array}{l}1.988^{* * *} \\
(0.216)\end{array}$ & $\begin{array}{l}0.957^{* * *} \\
(0.308)\end{array}$ & $\begin{array}{c}-0.533^{* *} \\
(0.221)\end{array}$ & $\begin{array}{c}-0.063 \\
(0.226)\end{array}$ & $\begin{array}{c}0.630 \\
(0.402)\end{array}$ & $\begin{array}{l}0.427^{* * *} \\
(0.057)\end{array}$ & $\begin{array}{l}0.203^{* * *} \\
(0.028)\end{array}$ & $\begin{array}{c}0.229^{*} \\
(0.137)\end{array}$ & $\begin{array}{l}0.460^{* * *} \\
(0.089)\end{array}$ & $\begin{array}{l}0.422^{* * *} \\
(0.082)\end{array}$ & $\begin{array}{l}0.438^{* * *} \\
(0.093)\end{array}$ \\
\hline$W(200)$ & $\begin{array}{c}24.652^{*} \\
(14.480)\end{array}$ & $\begin{array}{l}44.741^{* * *} \\
(13.900)\end{array}$ & $\begin{array}{c}10.927 \\
(17.452)\end{array}$ & $\begin{array}{l}85.474^{* * *} \\
(13.338)\end{array}$ & $\begin{array}{l}111.415^{* * *} \\
(17.178)\end{array}$ & $\begin{array}{l}46.045^{* *} \\
(23.035)\end{array}$ & $\begin{array}{c}-2.965 \\
(4.793)\end{array}$ & $\begin{array}{c}1.093 \\
(2.536)\end{array}$ & $\begin{array}{l}29.275^{* * *} \\
(7.745)\end{array}$ & $\begin{array}{l}12.764^{* *} \\
(5.329)\end{array}$ & $\begin{array}{l}18.364^{* * *} \\
(5.156)\end{array}$ & $\begin{array}{l}39.970^{* * *} \\
(6.306)\end{array}$ \\
\hline$W(375)$ & $\begin{array}{c}92.637^{* * *} \\
(11.926)\end{array}$ & $\begin{array}{l}135.129^{* * *} \\
(13.014)\end{array}$ & $\begin{array}{l}86.475^{* * *} \\
(17.088)\end{array}$ & $\begin{array}{c}82.463^{* * *} \\
(15.894)\end{array}$ & $\begin{array}{l}107.429^{* * *} \\
(15.733)\end{array}$ & $\begin{array}{l}48.351^{* *} \\
(23.377)\end{array}$ & $\begin{array}{c}5.881^{*} \\
(3.568)\end{array}$ & $\begin{array}{l}10.823^{* * *} \\
(1.834)\end{array}$ & $\begin{array}{l}37.525^{\text {*** }} \\
(8.246)\end{array}$ & $\begin{array}{l}33.825^{* * *} \\
(4.511)\end{array}$ & $\begin{array}{l}34.939^{* * *} \\
(4.308)\end{array}$ & $\begin{array}{l}19.451^{* * *} \\
(4.828)\end{array}$ \\
\hline$W(500)$ & $\begin{array}{l}109.355^{* * *} \\
(10.501)\end{array}$ & $\begin{array}{l}120.185^{* * *} \\
(12.038)\end{array}$ & $\begin{array}{c}30.320^{*} \\
(18.050)\end{array}$ & $\begin{array}{l}44.579^{* * *} \\
(13.206)\end{array}$ & $\begin{array}{l}78.329^{* * *} \\
(13.354)\end{array}$ & $\begin{array}{c}26.777 \\
(22.929)\end{array}$ & $\begin{array}{l}7.634^{* *} \\
(3.029)\end{array}$ & $\begin{array}{l}10.069^{* * *} \\
(1.641)\end{array}$ & $\begin{array}{l}25.176^{* * *} \\
(7.025)\end{array}$ & $\begin{array}{l}35.286^{* * *} \\
(4.132)\end{array}$ & $\begin{array}{l}28.191^{* * *} \\
(3.976)\end{array}$ & $\begin{array}{l}17.293^{* * *} \\
(4.465)\end{array}$ \\
\hline$H(200)$ & $\begin{array}{c}-0.068 \\
(0.214)\end{array}$ & $\begin{array}{c}-0.110 \\
(0.195)\end{array}$ & $\begin{array}{c}0.296 \\
(0.253)\end{array}$ & $\begin{array}{c}0.069 \\
(0.209)\end{array}$ & $\begin{array}{c}-0.766^{* * *} \\
(0.263)\end{array}$ & $\begin{array}{c}-1.655^{* * *} \\
(0.314)\end{array}$ & $\begin{array}{c}0.159^{* *} \\
(0.069)\end{array}$ & $\begin{array}{c}-0.238^{* * *} \\
(0.040)\end{array}$ & $\begin{array}{c}-1.411^{\text {*** }} \\
(0.127)\end{array}$ & $\begin{array}{c}-0.521^{* * *} \\
(0.111)\end{array}$ & $\begin{array}{c}-0.811^{\text {*** }} \\
(0.122)\end{array}$ & $\begin{array}{c}-1.248^{* * *} \\
(0.160)\end{array}$ \\
\hline$H(375)$ & $\begin{array}{r}-0.313^{*} \\
(0.177)\end{array}$ & $\begin{array}{c}-0.879^{* * *} \\
(0.194)\end{array}$ & $\begin{array}{c}-1.245^{* * *} \\
(0.245)\end{array}$ & $\begin{array}{c}-0.067 \\
(0.196)\end{array}$ & $\begin{array}{c}-0.512^{* *} \\
(0.226)\end{array}$ & $\begin{array}{r}-0.542^{*} \\
(0.311)\end{array}$ & $\begin{array}{c}-0.054 \\
(0.062)\end{array}$ & $\begin{array}{c}-0.282^{* * *} \\
(0.036)\end{array}$ & $\begin{array}{c}-1.104^{* * *} \\
(0.115)\end{array}$ & $\begin{array}{c}-0.866^{* * *} \\
(0.099)\end{array}$ & $\begin{array}{c}-1.108^{* * *} \\
(0.109)\end{array}$ & $\begin{array}{c}-0.815^{* * *} \\
(0.122)\end{array}$ \\
\hline$H(500)$ & $\begin{array}{c}-1.073^{* * *} \\
(0.164)\end{array}$ & $\begin{array}{c}-1.216^{* * *} \\
(0.175)\end{array}$ & $\begin{array}{c}-0.404 \\
(0.263)\end{array}$ & $\begin{array}{c}-0.236 \\
(0.166)\end{array}$ & $\begin{array}{c}-0.894^{* * *} \\
(0.196)\end{array}$ & $\begin{array}{c}-0.498 \\
(0.310)\end{array}$ & $\begin{array}{c}-0.105^{* *} \\
(0.053)\end{array}$ & $\begin{array}{c}-0.263^{* * *} \\
(0.037)\end{array}$ & $\begin{array}{c}-1.006^{* * *} \\
(0.118)\end{array}$ & $\begin{array}{c}-0.964^{* * *} \\
(0.095)\end{array}$ & $\begin{array}{c}-0.923^{* * *} \\
(0.099)\end{array}$ & $\begin{array}{c}-0.565^{* * *} \\
(0.122)\end{array}$ \\
\hline
\end{tabular}

Note: The table lists the results from repeating the earlier regression $P D_{t}=\beta_{0}+\beta_{1} S P E C_{t}+\beta_{2} V O L_{t}+\beta_{3} B A S I S_{t}+\beta_{4} F I N_{t}+\eta_{t}$ for the alternative window sizes of 200, 375 and 500 trading days, where $P D$ is either the component share $(C S)$, the information share $(I S)$ or the information leadership share $(I L S)$ and $S P E C$ is either of $T, W$ or $H$. T describes the level of total speculation, $W$ is the Working's T index and $H$ represents total hedging. $V O L$ and BASIS refer to trading volume and the basis spread, and FIN denotes the financialization dummy. Only the coefficient estimates of the speculation-related variables are reported. White-corrected heteroscedasticity-robust standard errors are provided in parentheses. Statistical significance is reported as ${ }^{*}$ for $p<0.1,{ }^{* *}$ for $p<0.05$ and ${ }^{* * *}$ for $p<0.01$. 
Appendix 
(a) Corn

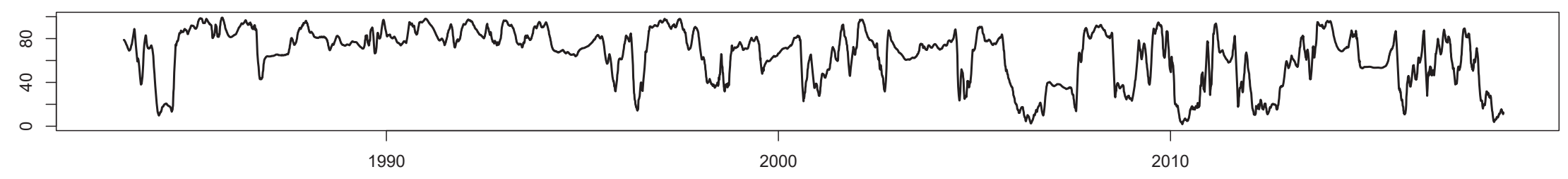

(b) Soybeans

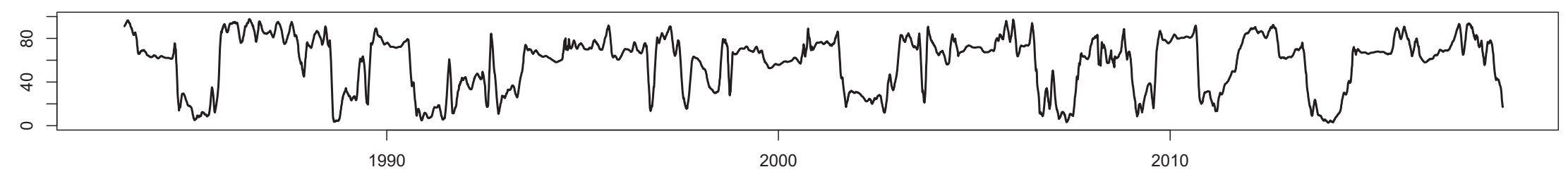

(c) Live Cattle

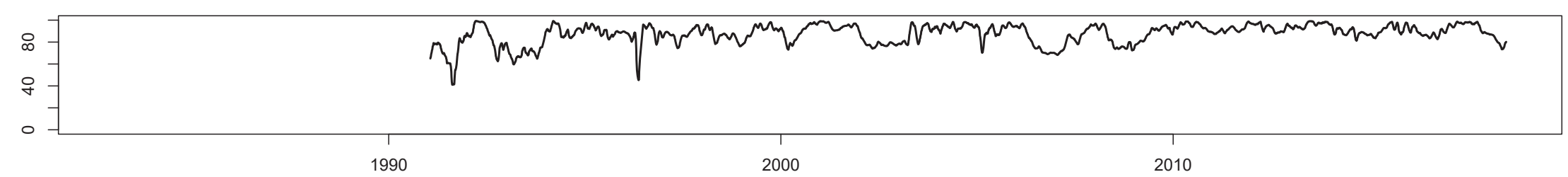

(d) Feeder Cattle

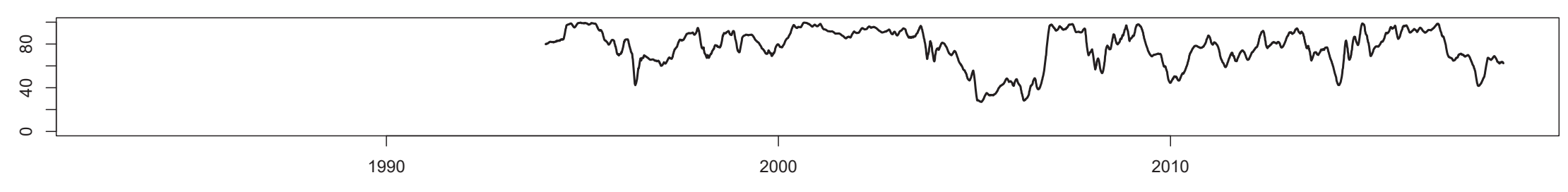

Figure 3: Futures Market Component Shares (Monthly Moving Average) 
(a) Corn

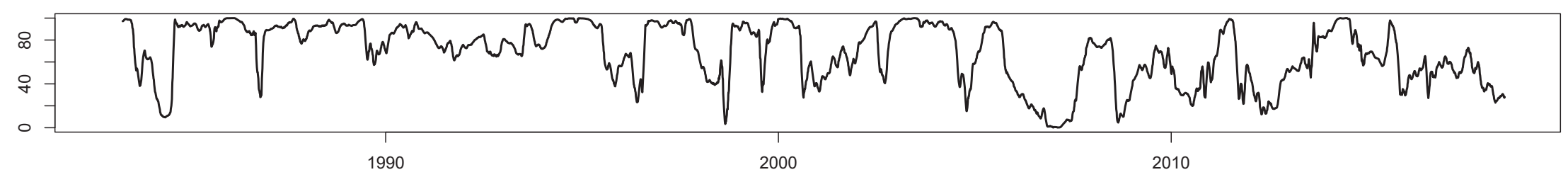

(b) Soybeans

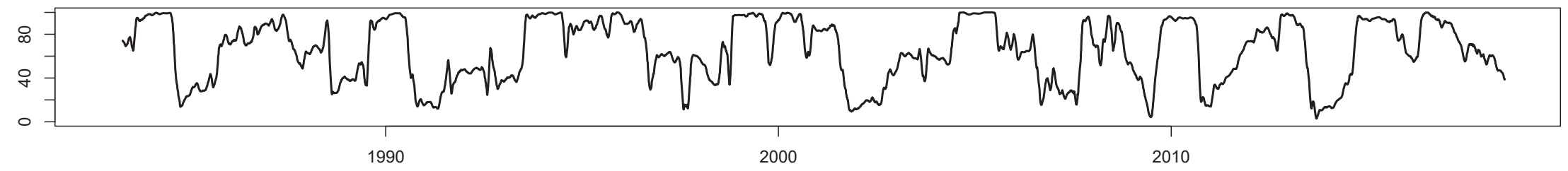

心

(c) Live Cattle

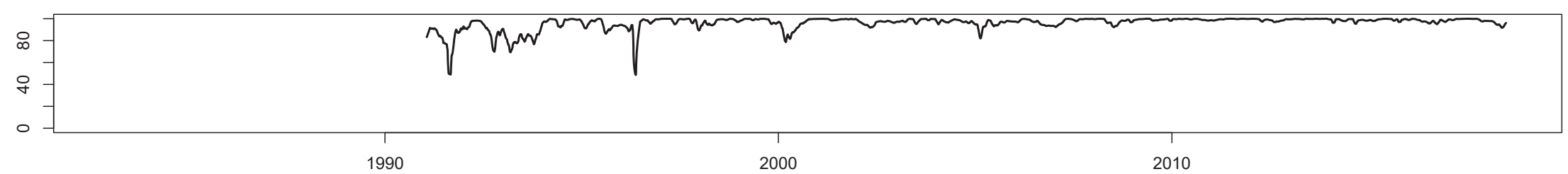

(d) Feeder Cattle

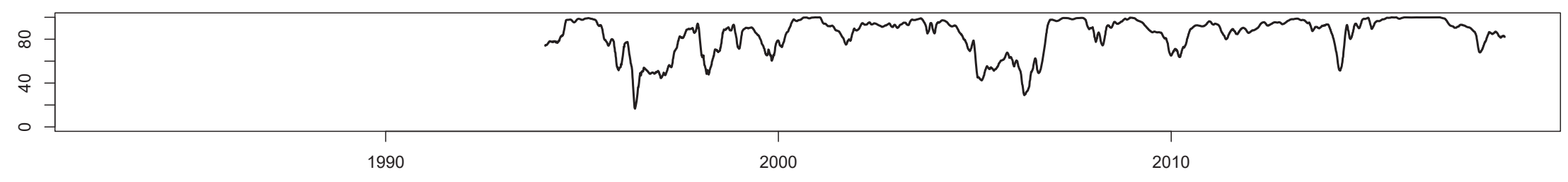

Figure 4: Futures Market Information Shares (Monthly Moving Average) 
(a) Corn

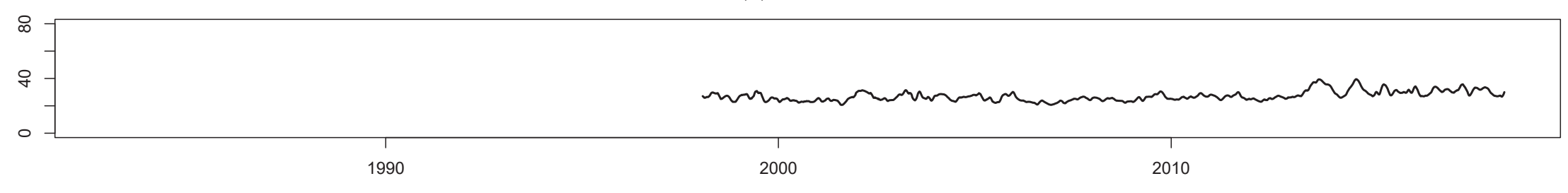

(b) Soybeans

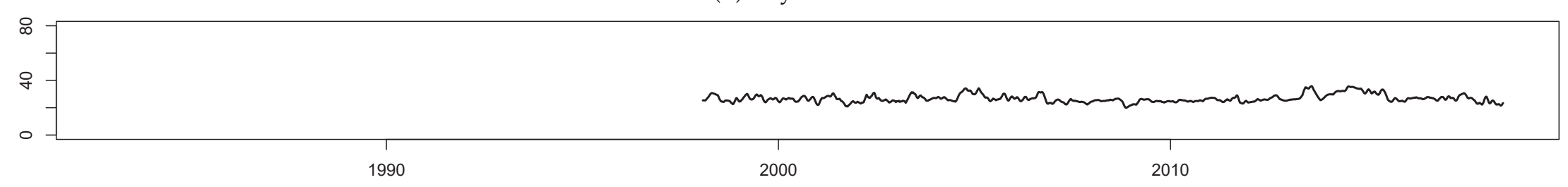

(c) Live Cattle

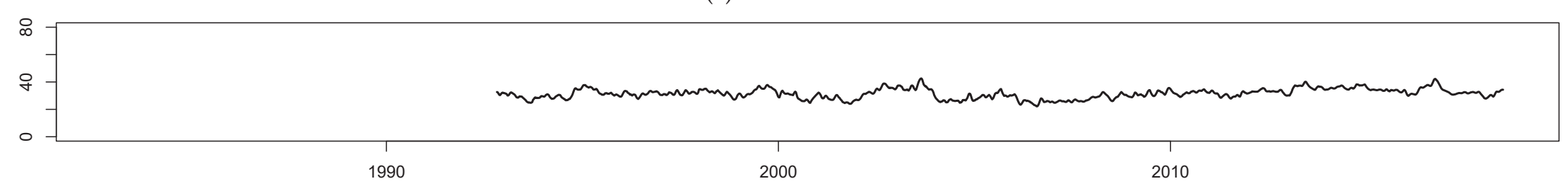

(d) Feeder Cattle

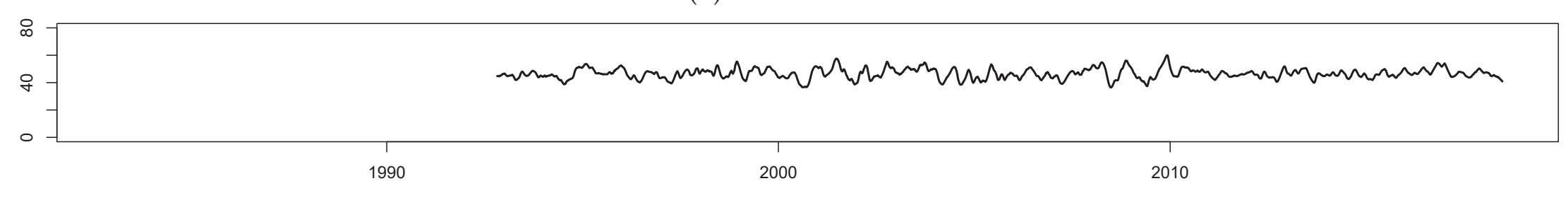

Figure 5: Total Speculation $\left(S_{t}\right)$ in the Futures Market (Monthly Moving Average) 
(a) Corn

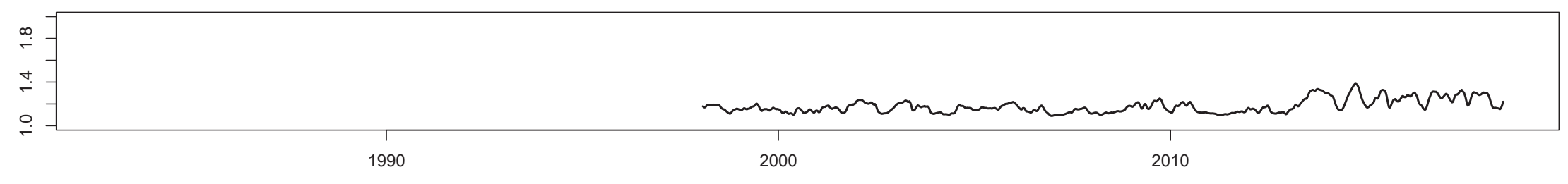

(b) Soybeans

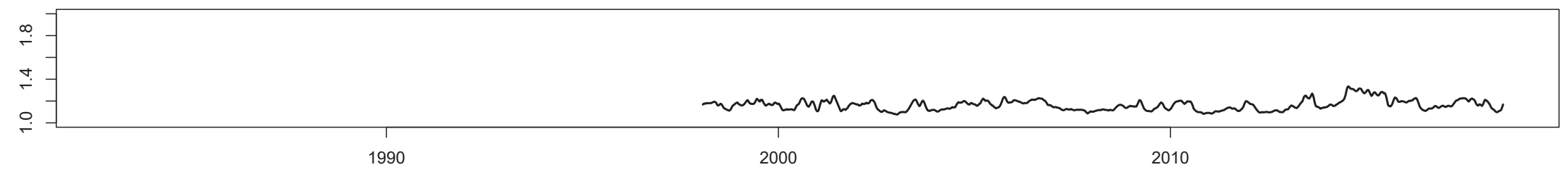

(c) Live Cattle

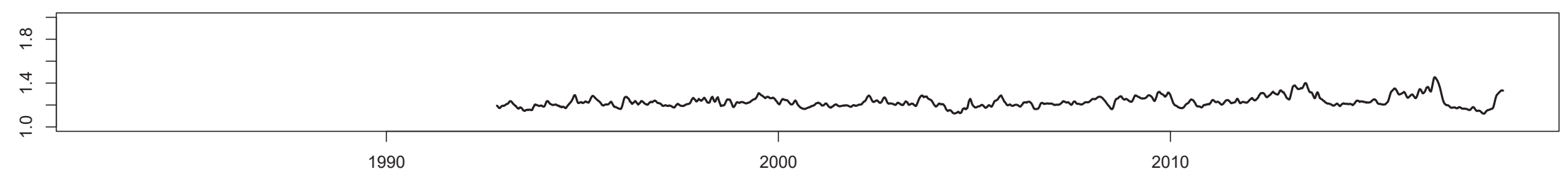

(d) Feeder Cattle

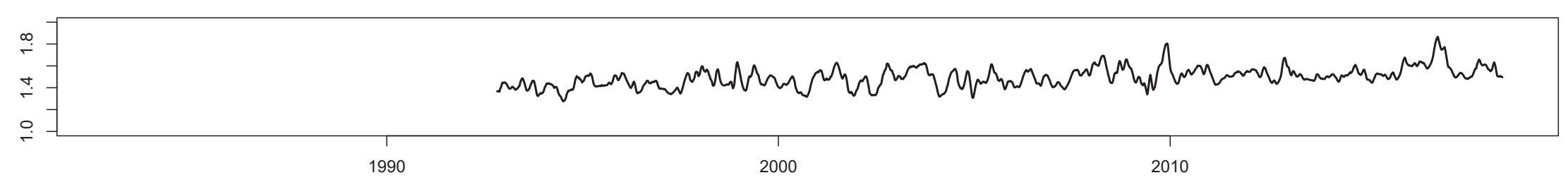

Figure 6: Excessive Speculation $\left(W_{t}\right)$ in the Futures Market (Monthly Moving Average) 
(a) Corn

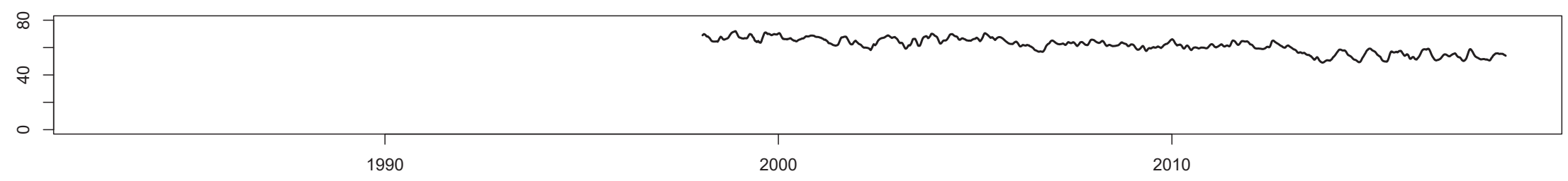

(b) Soybeans

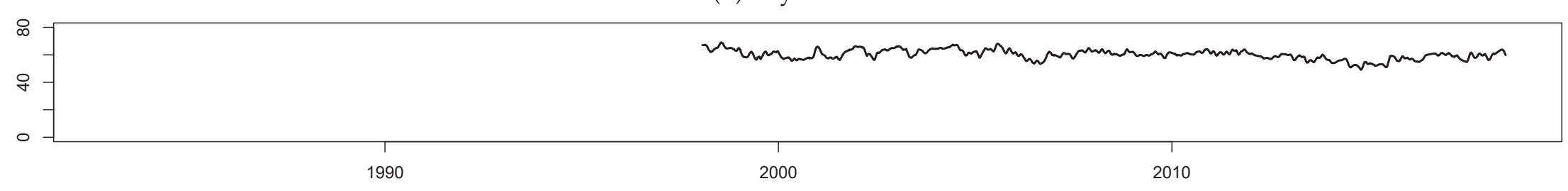

(c) Live Cattle

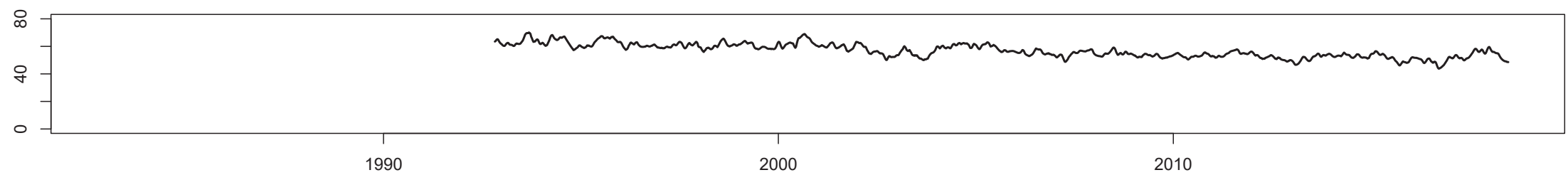

(d) Feeder Cattle

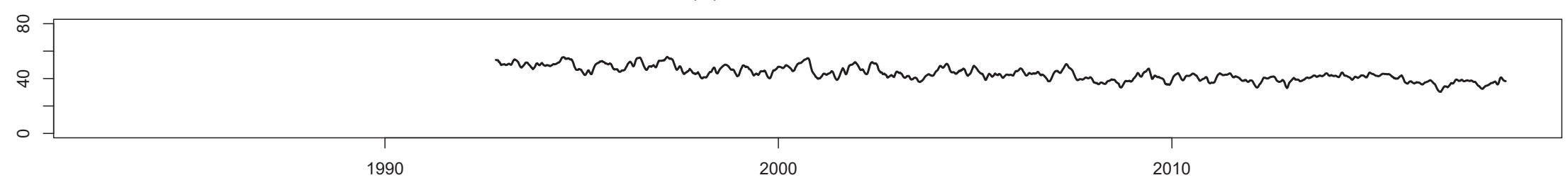

Figure 7: Total Hedging $\left(H_{t}\right)$ in the Futures Market (Monthly Moving Average) 
Table 8: Unit Root Tests

\begin{tabular}{|c|c|c|c|c|c|c|c|c|}
\hline \multirow[b]{2}{*}{ Variable } & \multicolumn{2}{|c|}{ Corn } & \multicolumn{2}{|c|}{ Soybeans } & \multicolumn{2}{|c|}{ Live Cattle } & \multicolumn{2}{|c|}{ Feeder Cattle } \\
\hline & $\mathrm{ADF}$ & PP & $\mathrm{ADF}$ & PP & $\mathrm{ADF}$ & PP & $\mathrm{ADF}$ & PP \\
\hline$C S$ & $-4.55^{* * *}$ & $-8.67^{* * *}$ & $-4.83^{* * *}$ & $-5.92^{* * *}$ & $-6.88^{* * *}$ & $-9.15^{* * *}$ & $-4.31^{* * *}$ & $-4.34^{* * *}$ \\
\hline$I S$ & $-4.86^{* * *}$ & $-5.78^{* * *}$ & $-3.82^{* *}$ & $-4.00^{* * *}$ & $-9.37^{* * *}$ & $-11.80^{* * *}$ & $-4.57^{* * *}$ & $-4.71^{* * *}$ \\
\hline$I L S$ & $-7.36^{* * *}$ & $-11.33^{* * *}$ & $-6.29 * * *$ & $-7.87^{* * *}$ & $-7.00^{* * *}$ & $-21.81^{* * *}$ & $-7.15^{* * *}$ & $-11.46^{* * *}$ \\
\hline$T$ & $-5.92^{* * *}$ & $-5.55^{* * *}$ & $-6.54^{* * *}$ & $-6.52^{* * *}$ & $-6.08^{* * *}$ & $-6.11^{* * *}$ & $-9.14^{* * *}$ & $-8.35^{* * *}$ \\
\hline$W$ & $-5.35^{* * *}$ & $-4.83^{* * *}$ & $-5.52^{* * *}$ & $-5.17^{* * *}$ & $-6.82^{* * *}$ & $-6.36^{* * *}$ & $-8.51^{* * *}$ & $-7.93^{* * *}$ \\
\hline$H$ & $-6.17^{* * *}$ & $-6.08^{* * *}$ & $-6.39^{* * *}$ & $-6.61^{* * *}$ & $-7.52^{* * *}$ & $-7.29^{* * *}$ & $-7.79^{* * *}$ & $-7.60^{* * *}$ \\
\hline$V O L$ & $-5.29^{* * *}$ & $-19.64^{* * *}$ & $-7.07^{* * *}$ & $-19.76^{* * *}$ & $-3.74^{* *}$ & $-29.33^{* * *}$ & $-4.98^{* * *}$ & $-22.98^{* * *}$ \\
\hline$B A S I S$ & $-4.37^{* * *}$ & $-5.76^{* * *}$ & $-6.61^{* * *}$ & $-8.74^{* * *}$ & $-7.94^{* * *}$ & $-10.51^{* * *}$ & $-8.33^{* * *}$ & $-13.86^{* * *}$ \\
\hline
\end{tabular}

Note: The table reports for log prices and log returns the critical values and p-values of the ADF and the PP test (both including a constant and a trend) as computed by Fuller (1996) and MacKinnon (1994), while the optimum lag-lengths have been determined using the Bayesian-Schwarz information criterion (1978). Statistical significance is reported as ${ }^{*}$ for $p<0.1{ }^{* *}$ for $p<0.05$ and ${ }^{* * *}$ for $p<0.01$. 